\title{
Republic of Armenia: Selected Issues
}

This Selected Issues paper for the Republic of Armenia was prepared by a staff team of the International Monetary Fund as background documentation for the periodic consultation with the member country. It is based on the information available at the time it was completed on November 3 , 2006. The views expressed in this document are those of the staff team and do not necessarily reflect the views of the government of the Republic of Armenia or the Executive Board of the IMF.

The policy of publication of staff reports and other documents by the IMF allows for the deletion of market-sensitive information.

To assist the IMF in evaluating the publication policy, reader comments are invited and may be sent by e-mail to publicationpolicy@imf.org.

Copies of this report are available to the public from

International Monetary Fund $\bullet$ Publication Services

700 19th Street, N.W. • Washington, D.C. 20431

Telephone: (202) 6237430 • Telefax: (202) 6237201

E-mail: publications@imf.org • Internet: http://www.imf.org

Price: $\$ 18.00$ a copy

\section{International Monetary Fund Washington, D.C.}





\section{INTERNATIONAL MONETARY FUND}

\section{REPUBLIC OF ARMENIA}

\section{Selected Issues}

Prepared by Holger Floerkemeier, Nienke Oomes (MCD), David Hauner (FAD), and Ruben Atoyan (PDR)

Approved by Middle East and Central Asia Department

November 3, 2006

Contents

I. Remittances to Armenia: Size, Sources, and Macroeconomic Implications .4

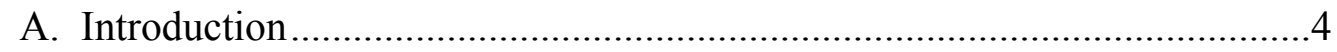

B. Size and Sources of Remittances to Armenia ..............................................5

C. Measuring Remittances Using Balance of Payments Statistics ..................8

D. The Macroeconomic Effects of Remittances ..........................................10

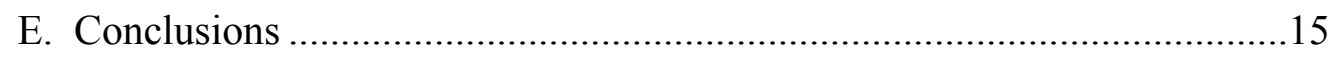

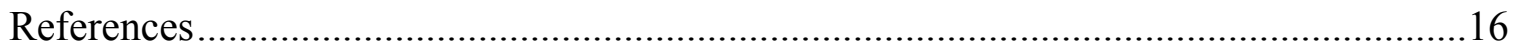

II. Armenia's Low Tax Revenues: Reasons, Recent Reforms, and Next Steps .........17

A. Introduction and Summary............................................................ 17

B. Reasons for Armenia's Low Tax Revenue ............................................18

C. Recent Reforms ...................................................................................23

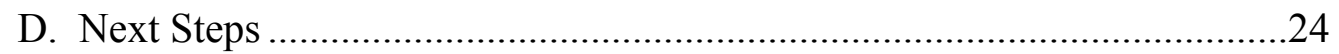

III. Armenia's Financial System: Why is it Small and What Reforms Are Needed?...27

A. Overview .......................................................................................2 27

B. Size, Structure, and Stability of the Financial Sector .............................28

C. Obstacles to Financial Sector Development …..........................................35

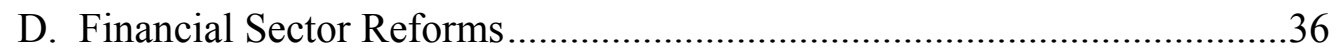

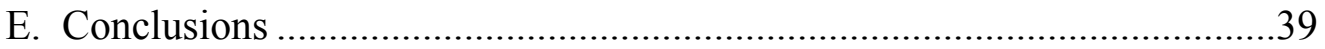

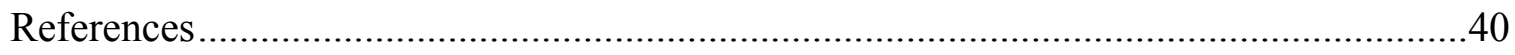

Boxes

I.1. Estimates of the Official BOP Statistics in Armenia ........................................... 
Figures

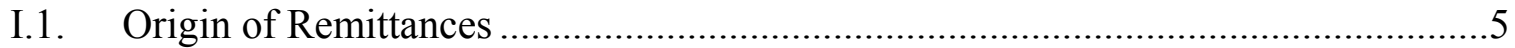

I.2. Estimated Remittances Inflows, 2005 ................................................................ 7

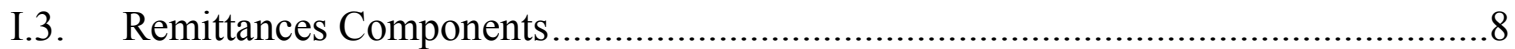

I.4. Other Remittances and Real Estate Prices ....................................................

I.5. GDP Growth in Russia and Remittances Inflows to Armenia: Correlogram .........10

I.6. Macroeconomic Impact of Remittances: Correlogram ........................................11

I.7. Response to One S.D. Innovation in Other Remittances .....................................13

I.8. Response to One S.D. Innovation in Other Remittances ........................................13

I.9. Response to One S.D. Innovation in Personal Remittances ...................................13

I.10. Response to One S.D. Innovation in Personal Remittances .................................13

I.11. Response to One S.D. Innovation in Total Remittances .....................................15

II.1. Revenue by Tax in Selected Transition Countries, 2005 ....................................19

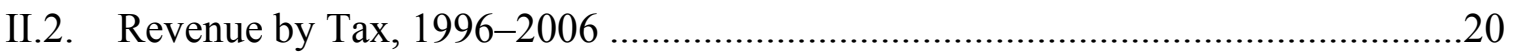

II.3. Change in Ratio of Individual Taxes to GDP, 2000-06 ........................................22

II.4. Estimated Contributions to Change in Total Tax Revenue, 2003-06....................23

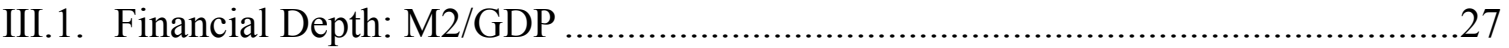

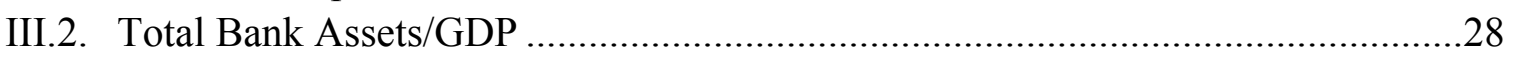

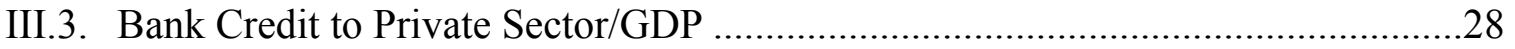

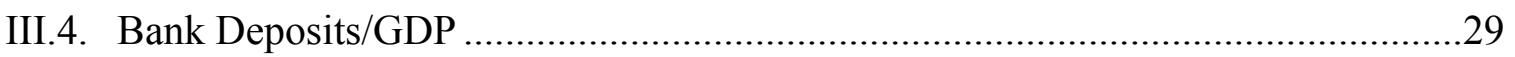

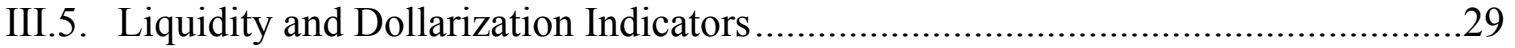

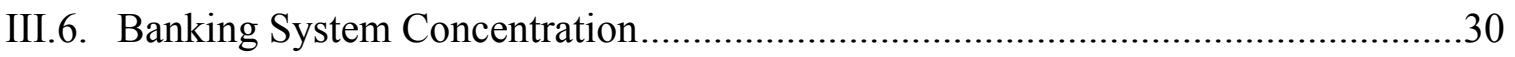

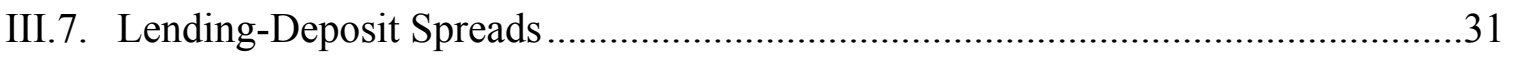

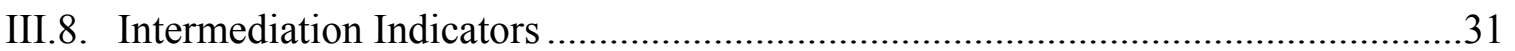

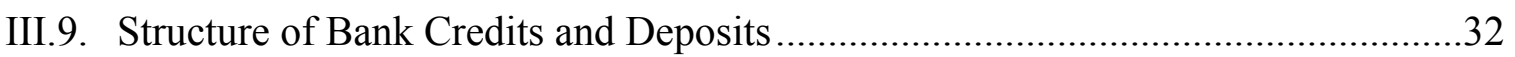

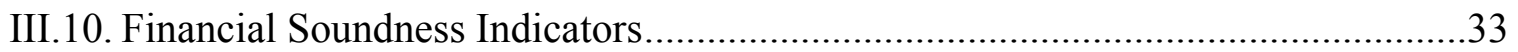

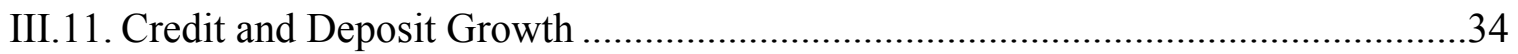

Tables

I.1. Estimates of the Share of Remittances Sent Through Banks...............................6

I.2. Pairwise Granger Causality Tests ................................................................... 14

I.3. Variance Decomposition........................................................................... 14

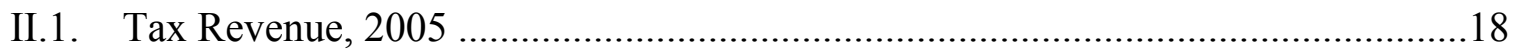

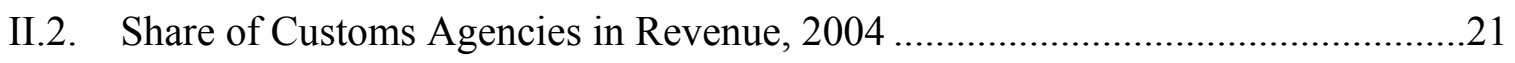

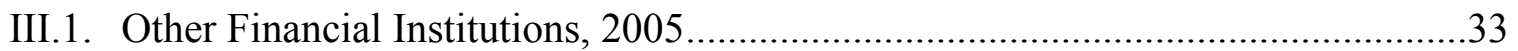

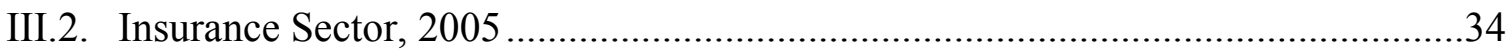

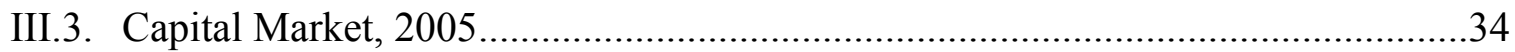


III.4. EBRD Transition Index and Financial Sector Reform ........................................36

III.5. World Bank Doing Business 2007 and Financial Sector Reform............................37 


\section{Remittances to ARMenia: Size, SOURCES, AND MACROECONOMIC IMPLiCATIONS ${ }^{1}$}

\section{A. Introduction}

1. Remittances play an important role in the Armenian economy. While Armenia itself has a population of only about 3 million, an estimated 8 million Armenians live abroad. $^{2}$ The "old diaspora," which left several generations ago, is mostly based in the Middle East, the United States, and Europe, while the "new diaspora," which left following the collapse of the Soviet Union, is largely based in Russia. In addition, many Armenians conduct temporary work abroad, mostly in Russia. Members of all three groups maintain close ties with Armenia, and send large amounts of remittances back home.

\section{This chapter provides an overview of the size, sources, and macroeconomic} implications of remittances to Armenia. Based on a combination of survey data and data on money transfers reported by banks, we find that (i) remittances constitute a significant share of income and GDP; (ii) remittances are mainly sent from Russia, and are strongly correlated with Russian GDP growth; (iii) most remittances to Armenia are sent through banks in the form of money transfers; (iv) "traditional remittances," which are sent by Armenians who temporarily or permanently work abroad, have a positive effect on consumption, but do not appear to significantly affect GDP growth; (v) "other remittances," which are likely associated with investment into real estate, seem to have a positive effect on both investment and GDP growth; (vi) a one percent of GDP increase in total remittances leads to a one percentage point increase in dram appreciation.

3. This chapter is organized as follows. We start by discussing the size and the sources of remittances to Armenia. We then discuss the appropriate definition of remittances, and subsequently present estimates of the macroeconomic effects of remittances to Armenia. Finally, we conclude by summarizing our main findings.

\section{B. Size and Sources of Remittances to Armenia}

4. Remittances constitute a significant share of Armenians' total income. A recent household survey commissioned by the Central Bank of Armenia (CBA, 2006) ${ }^{3}$ found that

\footnotetext{
${ }^{1}$ Prepared by Ruben Atoyan and Nienke Oomes. The authors would like to thank Natalia Ivanik and Thomas Elkjaer for useful suggestions and stimulating discussions on the definition and measurement of remittances.

${ }^{2}$ According to estimates from the Armenian Ministry of Foreign Affairs for 2005, the largest Armenian populations outside Armenia live in Russia (2.2 million), the United States (1.4 million), Georgia (460,000), France (450,000), Iran (150,000), Ukraine (150,000), Argentina (130,000), Lebanon (130,000), Syria (100,000), and Poland $(100,000)$.

${ }^{3}$ This survey, henceforth referred to as "CBA (2006)," was financed by the World Bank and carried out by Alphaplus Consulting during February-April 2006. The sample consisted of 2000 Armenian households that
} 
37 percent of Armenian households regularly receive remittances. Around 75 percent of remittances senders are close relatives, while another 20 percent are distant relatives. ${ }^{4}$ For those households who received remittances, the estimates of the share of remittances in total household income range from about 25 to 80 percent. ${ }^{5}$ As a result, households that have been receiving remittances have been able to move, on average, from the lower to the middle income class bracket (CBA, 2006).

\section{Most remittances to Armenia are} sent from Russia (Figure I.1). According to the CBA Survey (2006), about 72 percent of total remittances (from both seasonal workers and emigrants) is coming from Russia. In particular, remittances sent by seasonal workers are almost exclusively Russian in origin. Similarly, banks report that about 80 percent of money transfers are sent from Russia. The CBA (2006) survey also finds

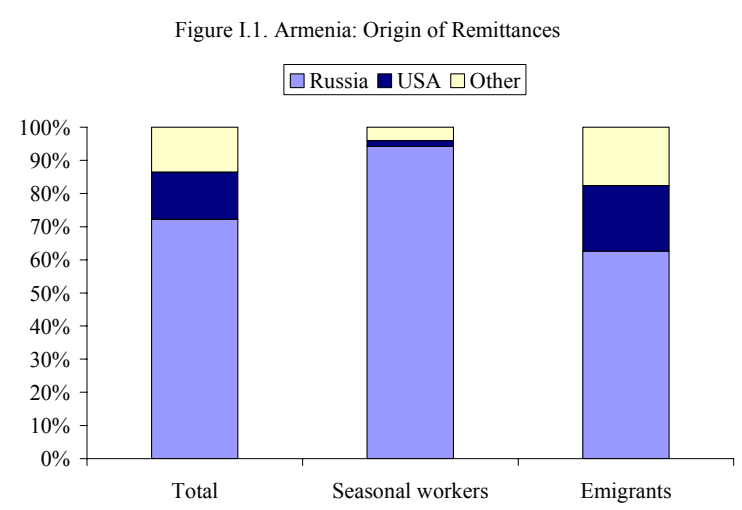
that between 47 and 68 percent of remittances senders from Russia work in construction or trade. ${ }^{6}$ These are the nontradables sectors that have boomed following the recent surge in oil prices, consistent with the "spending effect" of Dutch disease (Oomes and Kalcheva, 2006). It appears, therefore, that remittances to Armenia depend strongly on GDP growth in Russia.

6. Most remittances to Armenia are sent in U.S. dollars. According to the CBA (2006), about 90 percent of remittances in 2005 were received in the form of U.S. dollars, while only 7 percent were received in Russian rubles, and the remaining 3 percent in euros.

receive remittances and 2000 senders of remittances from Moscow. At the end of 2006, this survey will be complemented with results from an additional survey of remittances senders from the United States, financed by USAID. Unless otherwise noted, survey results reported in this chapter are based on the CBA (2006) survey.

${ }^{4}$ Similarly, 90 percent of remittances senders from Moscow report that the main reason for sending remittances is to help relatives. Note, however, that these percentages are not weighted by the amount of remittances sent.

${ }^{5}$ This share was estimated at 24 percent by CBA (2005), at 48 percent by CBA (2006), and at 80 percent by Roberts and Banaian (2005). The large differences could be due to the relatively small sample sizes, and to the fact that some surveys (e.g., CBA 2005) cover the entire population while other surveys (e.g., CBA 2006) cover only that part of the population that receives remittances.

${ }^{6}$ The survey of Armenian households suggests that 47 percent of remittances senders from Russia work in construction, while the survey of remittances senders from Moscow suggests that this percentage is 27 percent. Both surveys find that about 20 percent of Russian remittances senders work in the trade sector. 
7. Most remittances to Armenia are sent through the banking system (Table I.1). The likely reasons for this are that money transfers are relatively inexpensive (around 1 percent for noncommercial transfers), quick (often within 30 minutes), and generally reliable. The price of money transfers to Armenia has come down significantly because there are several local and regional money transfer systems that offer competitive rates compared with Western Union and Money Gram. ${ }^{7}$ According to the CBA Survey (2006), only about 22 percent of total remittances - and only 13 percent for remittances from Russia - are sent by other means, e.g., in cash or in kind via returning migrants, friends, or relatives. Other surveys give similar results.

Table I.1. Estimates of the Share of Remittances Sent Through Banks

(In percent)

\begin{tabular}{ll}
\hline CBA Survey on Dollarization (2005) & 56 \\
World Bank (2003) & 62 \\
Roberts and Banaian (2005) & 74 \\
CBA Survey on Remittances (2006) & 78 \\
Emigration Survey (2005) & 85 \\
\hline
\end{tabular}

Source: CBA Survey on Remittances (2006)

\section{Given the large share of remittances sent through banks, estimating remittances} using bank data on money transfers has several advantages over using household surveys. First, survey data tend to significantly underestimate the value of remittances, as survey respondents (particularly, recipients of remittances) may be hesitate to truthfully disclose the amount of remittances received. Second, since bank data are collected at the transaction level, they are more reliable, more detailed, and available at a high frequency. Third, it is relatively inexpensive to collect the data from banks, compared with the cost of conducting surveys.

\section{There are large discrepancies between survey estimates of remittances and} estimates based on money transfers reported by banks (Figure I.2). While it is understood that surveys likely underestimate the true amount of remittances, it is interesting to note that three different surveys all suggest a similar value for remittances in 2005 (amounting to US\$200-300 million), while the data based on bank report forms suggest a significantly higher number (US\$753 million). Moreover, the CBA (2006) argues that the latter estimate

\footnotetext{
${ }^{7}$ Roberts and Banaian (2005, Table 3.3) show that since 2001, the money transfer systems Anelik and Unistream have been the dominant transfer systems used in Armenia.
} 
still needs to be adjusted by the estimated share of nonbank transfers, which gives a total number of almost US\$1 billion. ${ }^{8}$

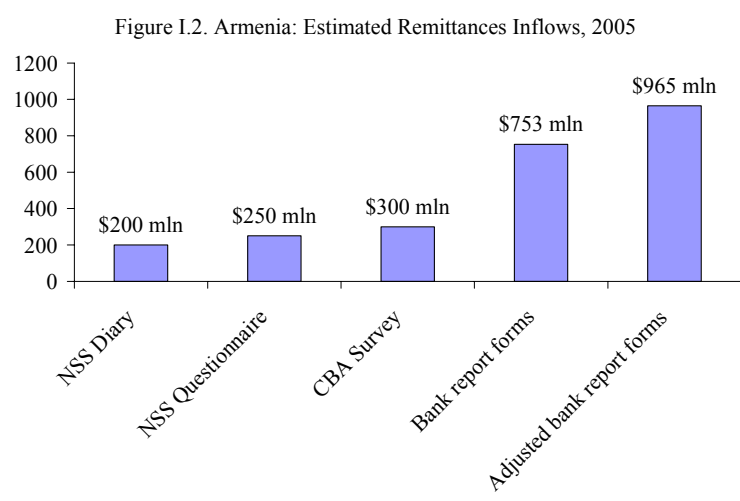

10. While bank data on money transfers may underestimate remittances because they do not include cash or in kind transfers, there are also several reasons why they could overestimate remittances. First, since it is less expensive to make a noncommercial transfer for amounts up to US\$5,000, there is an economic incentive for transferees to classify commercial transfers as noncommercial. While any transfer between households above US\$20,000 is automatically classified as commercial, it is possible that certain commercial transfers below US\$20,000 are classified as noncommercial current transfers. Similarly, while transfers by a legal entity are considered commercial and should thus be sent via the more expensive channel, there is an economic incentive for representatives of legal entities to make transfers in their identity as physical persons, which could lead to an overrepresentation of noncommercial transfers. One indication that this misclassification may be going on is that the average size of noncommercial transactions in 2005 (US\$692) is almost double the average size of remittances reported via the CBA survey (US\$353 in 2005). ${ }^{9}$

\section{A likely source of misclassification is that foreign investments in real estate may} be incorrectly classified as noncommercial. Even though transfers above US\$20,000 are automatically classified as commercial payments, investments in real estate can potentially be less than that. For example, if a down payment or installment is paid, it can easily be classified as a noncommercial transfer, or transferees may on purpose send the payment in smaller pieces so as to benefit from the lower transfer fee. If the transfer is sent by a nonresident with the purpose of purchasing real estate for an Armenian resident, such a transfer is a capital transfer and should technically still be considered as part of remittances. However, if nonresidents intend to purchase real estate for themselves, their corresponding transfers should be considered as foreign direct investments, rather than as remittances.

\footnotetext{
${ }^{8}$ Assuming that US\$753 is only 78 percent of total remittances, as suggested by the CBA (2006) survey, total remittances would be US\$965 million.

${ }^{9}$ However, the average size of remittances reported by remittances senders in Moscow was US\$560 (CBA, 2006).
} 


\section{Measuring Remittances using Balance of Payments Statistics}

12. For the purpose of this study, total remittances are divided into two categories: "traditional remittances" and "other remittances" (Box I.1). Similar to many studies on remittances, the "traditional remittances" are defined as the sum of workers' remittances and compensation of employees. Workers' remittances are current transfers sent by workers who live abroad for more than one year, and who are therefore considered non-residents. For Armenia, this includes both the "old diaspora" and the "new diaspora." Compensation of employees refers to the compensation earned abroad by temporary (e.g., seasonal) workers who live abroad for less than one year, and are therefore still considered residents. "Net" compensation of employees is the part of gross compensation that is sent home, after subtracting expenditures on travel and passenger transportation, income taxes, and social contributions. "Other remittances" include gifts, dowries, inheritances, alimony, private pensions, and other support received from non-resident households regardless their source of income or the purpose of the transfer. ${ }^{10}$

\section{The official balance of payments} statistics for Armenia suggest that the largest type of remittances is other remittances. (Figure I.3). ${ }^{11}$ The net total remittances inflows increased from about 5 percent of GDP (US\$103 million) in 1996 to over 10 percent of GDP (US\$481 million) in 2005. ${ }^{12}$ However, there is a substantial degree of heterogeneity in the different types of remittances. Workers' remittances declined

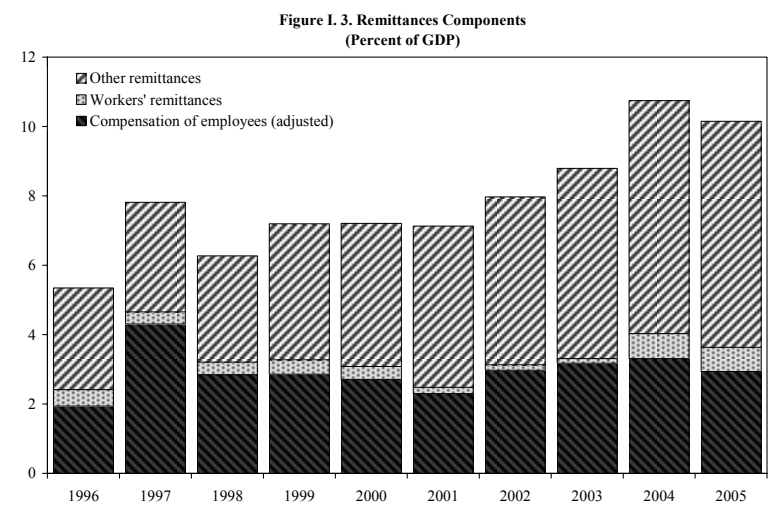
somewhat in 2001-03, grew significantly in 2004-05, but still constitute a relatively small share of total remittances. In contrast, inflows associated with the compensation of employees (temporary workers) have been much larger, and have been broadly stable over the past decade, averaging around 3 percent of GDP per annum. The largest inflows, however, have been other remittances. They more than doubled, increasing from about 3

\footnotetext{
${ }^{10}$ The inclusion of "other remittances" in the official BOP statistics was recently recommended by the United Nations Technical Subgroup on the Movement of Natural Persons (TSG, 2006).

${ }^{11}$ All series are as reported in the International Financial Statistics' balance of payments statistics for Armenia, and are "net" in the sense that we take inflows minus outflows (i.e., we subtract remittances and other remittances sent from Armenia to other countries).

12 These net figures are not fully comparable with the gross remittances inflows reported in Figure 2. Gross inflows recorded in the official balance of payment statistics account for US\$630 million in 2005.
} 
percent of GDP in 1996 to over 61/2 percent of GDP in 2005, and currently constitute by far the largest type of inflow.

\section{Box I.1. Estimates of the Official BOP Statistics in Armenia}

The official balance of payments statistics (BOP) for Armenia are compiled using both bank report forms and household surveys. In particular, the National Statistics Service (NSS) uses the results of household surveys to divide the recorded inflow of total private transfers through the banking system (\$753 million for 2005) into four components: compensation of employees (about 45 percent of total), foreign direct investment (about 3.5 percent), private capital transfers (about 3 percent) and other private current transfers, where the latter is a residual (about 48.5 percent). The NSS then augments the latter category by assuming that a certain amount of private current transfers enter the country in cash or in kind. Finally, the category "workers' remittances" is assumed to be a certain share (about 8 percent) of total (augmented) private current transfers. The NSS is in the process of improving its methodology for allocating total private transfers across the separate BOP components.

The official BOP reporting requires recording of the compensation of employees in "gross" terms, neccesitating an adjustment of bank data. The estimate of compensation of employees arrived at the abovementioned way is, in fact, a "net" estimate of the part of temporary workers' salaries that is in fact sent back home. In contrast, the compensation of employees category in the balance of payments statistics is a "gross" estimate of the total compensation earned by temporary workers abroad. The NSS computes this gross figure by taking the net figure and grossing it up by assuming that roughly two thirds of earned compensation is sent back home. The remaining one third is then allocated to other components of the balance of payments, including "travel" (for housing, food, clothing, etc.) and "general government current transfers" (for taxes and social payments to host country governments).

Other private current transfers are likely to include capital transfers for the purpose of buying capital goods (e.g., housing or land), as it is difficult to distinguish between capital and current transfers, since remittances senders and receivers themselves may not immediately decide on the use of remittances. The NSS plans to adjust its balance of payments statistics by including a question in its questionnaire that asks whether senders send remittances for the purpose of buying real estate, and, if so, whether this is for themselves or for someone else.

\section{The large increase in other} remittances has been roughly in line with the surge in real estate prices, confirming the hypothesis that some of these remittances may have been used for investment into real estate (Figure

I.4). Real estate prices approximately tripled in the last four years, and doubled in the last two years, in line with other private transfers. Given that data on real estate prices are not available prior to

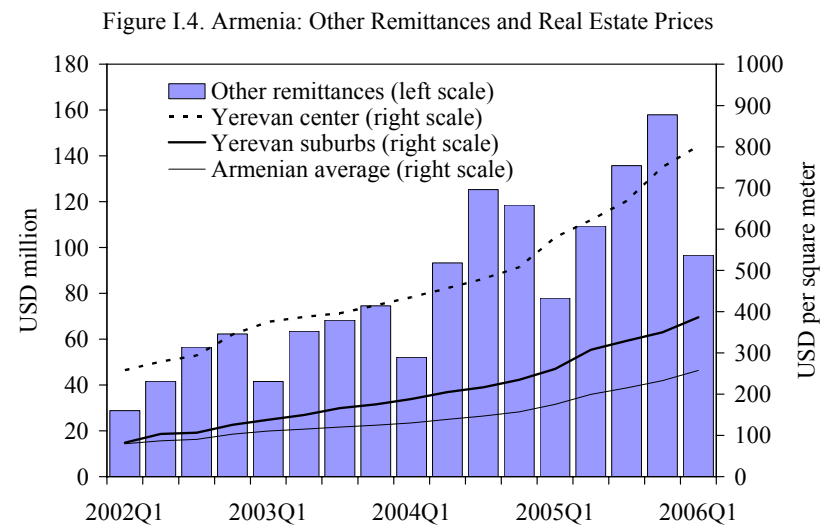

2002 , it was not possible to study this relationship using more formal econometric analysis. 
Nevertheless, the strong correlation could be an indication that a significant share of noncommercial money transfers are, in fact, investments into real estate.

\section{There is a strong correlation between other remittances and Russian GDP}

growth (Figure I.5). Statistical analysis confirms that remittances inflows to Armenia are positively correlated with Russian economic growth. ${ }^{13}$ The positive correlation with Russia's GDP growth, however, is more pronounced for other remittances than for traditional remittances (defined as the sum of workers' remittances and compensation of employees). Indeed, the correlograms suggest that contemporaneous correlation between GDP growth in Russia and other remittances is of the order of 0.6, while Russia's current economic performance is also significantly correlated with the future other remittances inflows to Armenia (the correlation coefficient after four quarters is about 0.4).

Figure I.5. GDP Growth in Russia and Remittances Inflows to Armenia: Correlogram
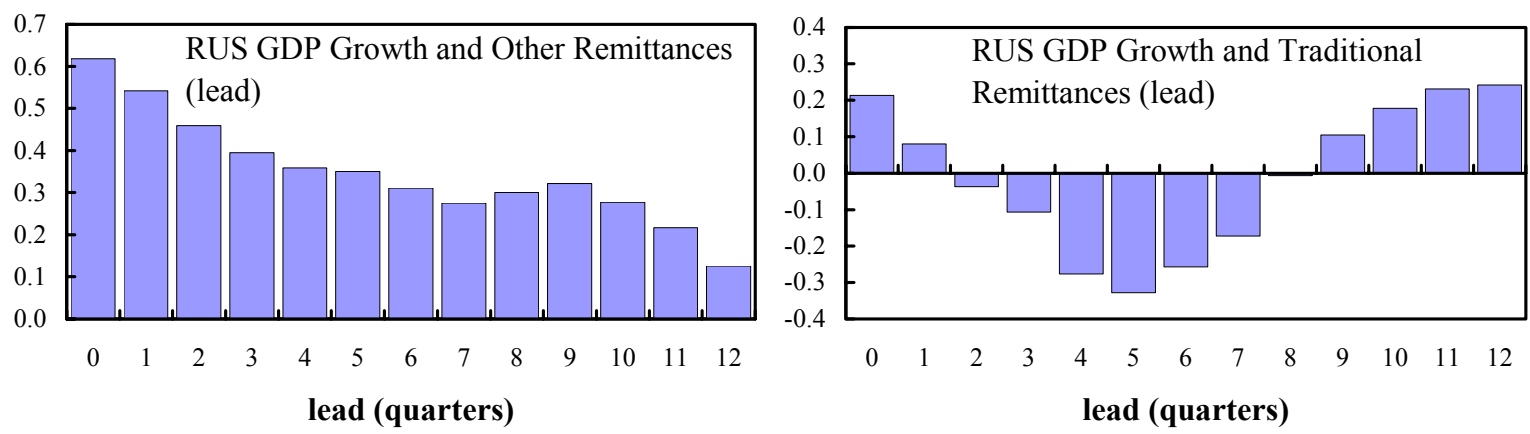

\section{The Macroeconomic Effects of Remittances}

\section{Effects on consumption, investment, and GDP growth}

\section{The effect of remittances on economic growth depends on the extent to which} remittances are used for consumption or investment. On the one hand, if remittances are mainly used for investment in human or physical capital, they are expected to have a positive effect on growth. On the other hand, if remittances are mainly used for consumption, they can induce "moral hazard" and may influence labor supply, investment, and government policy making. ${ }^{14}$

\footnotetext{
${ }^{13}$ Correlograms report cross-correlation coefficients between the two series, assuming the lag-lead structure specified by the number of quarters on the horizontal axis.

${ }^{14}$ See Roberts and Banaian (2005) for a more thorough discussion on the potential costs and benefits of remittances.
} 
17. Empirical studies find that, on average, about 60 percent of remittances are used for consumption. Roberts and Banaian (2005) discuss four studies that have empirically assessed the use of remittances in Egypt, Greece, Guatemala, and Pakistan. These studies find that, on average, about 60 percent of remittance income is consumed, while the rest is largely invested in housing, land, and shops - particularly when financial sectors are undeveloped.

18. In Armenia, traditional remittances appear to mainly affect consumption, while other remittances have a stronger effect on investment. ${ }^{15}$ As Figure I.6 shows, there exists a negative contemporaneous correlation between consumption and remittances, which could indicate that remittances are countercyclical. Nevertheless, traditional remittances appear to

Figure I.6. Macroeconomic Impact of Remittances: Correlogram
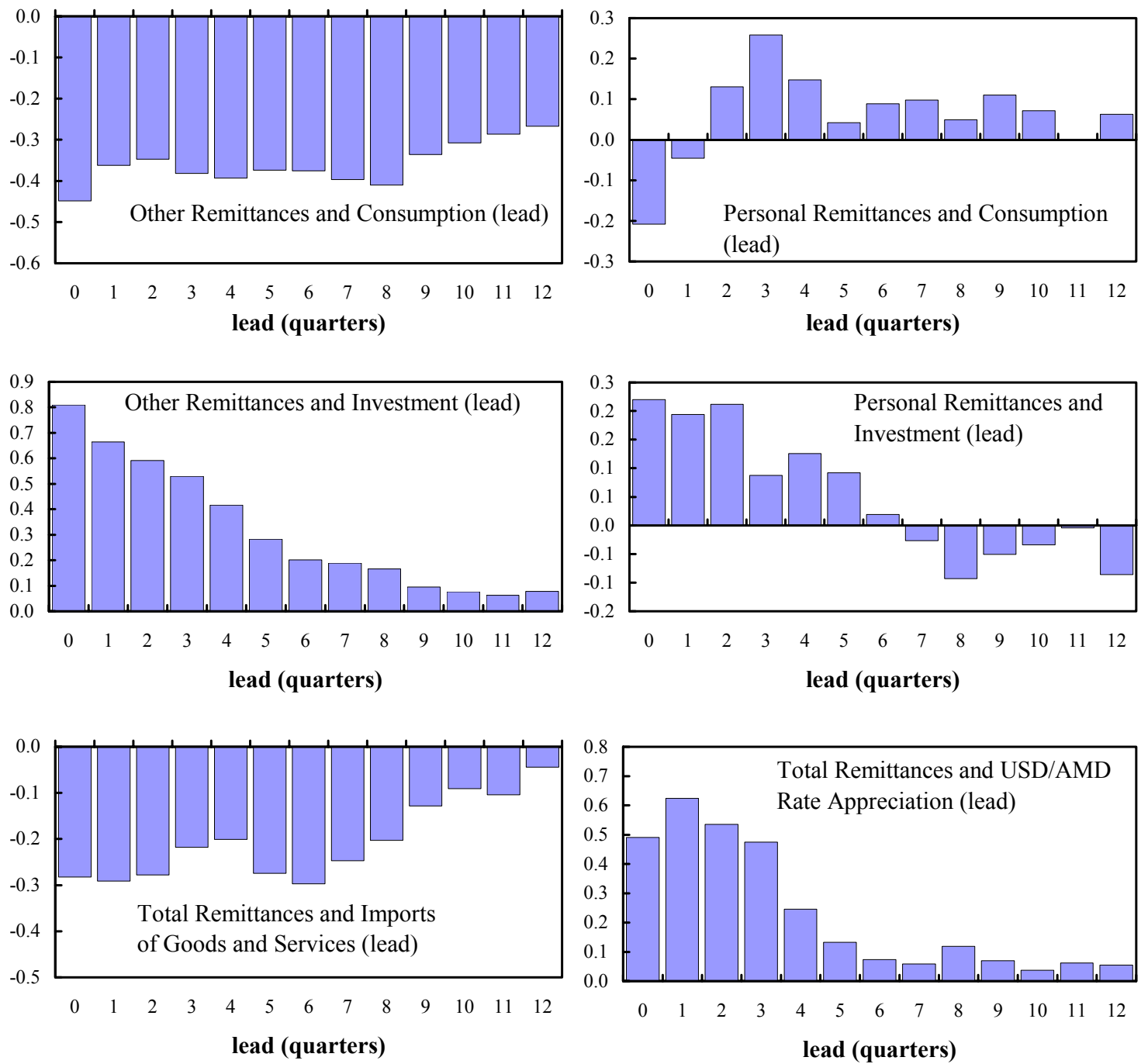

\footnotetext{
${ }^{15}$ The results reported in this section of the paper are estimated over a sample of quarterly data between the first quarter of 1996 and the fourth quarter of 2005.
} 
be associated with somewhat higher future consumption (the correlation coefficient between personal remittances inflows and consumption four quarters latter is about 0.3 ), while the correlation between other remittances and consumption remains negative (the correlation coefficient between other remittances and future consumption is estimated to fluctuate around 0.4 , irrespective of the number of leads for consumption series). Other remittances, however, are strongly and positively correlated with future higher investment rates, with the contemporaneous correlation coefficient of 0.8 gradually declining to about 0.4 over the first four quarters.

\section{To further investigate the plausibility of descriptive results suggested by the} correlograms, we contrast them with results from a more formal Vector Auto Regression (VAR) reduced-form model. Under the alternative specifications of this approach, we assume that remittances inflows influence either consumption or investment in the economy, each of which, in turn, is assumed to affect dynamics of real GDP growth. ${ }^{16}$ We then gauge the macroeconomic impact of remittances by analyzing impulse response functions, which simulate how consumption, investment, and GDP growth would respond to an exogenous increase in remittances.

\section{Consistent with previous findings, our VAR analysis indicates that other} remittances considerably affect investment rates in Armenia, with no significant impact on consumption (Figures I.7 and I.8). ${ }^{17}$ The impulse response functions from our estimated VAR model suggest that a temporary increase in other remittances of about $1 / 2$ percent of GDP results in a persistent boost to the investment-to-GDP ratio that peaks also at $1 / 2$ percent of GDP in about four quarters after the shock. There is also some evidence that the increased transfers are positively associated with higher future economic growth rates.

21. In contrast, positive shocks to traditional remittances are associated with sizable increases in Armenia's consumption but have no statistically significant effect on investment (Figures I.9 and I.10). The magnitude of the impact is sizable, as a $3 / 4$ percent of GDP increase in traditional remittances results in a $1 \frac{1}{2}$ percent of GDP higher consumption in the economy within the year of the initial shock. ${ }^{18}$ Simulations further show that the consumption

\footnotetext{
${ }^{16}$ The time series on foreign currency inflows, consumption, and investment are seasonally adjusted and expressed in percent of GDP. Real GDP growth is expressed in percentage points. Specification tests indicated that two lags of endogenous variables should be included in the model.

${ }^{17}$ Consumption in fact exhibits a pronounced—but statistically insignificant—-decline in response to a shock in other remittances, perhaps reflecting the possibility that remittances finance investment only partially, with additional financing coming from domestic savings.

${ }^{18}$ The shape of the impulse response function for consumption is very similar to the relationship suggested by the correlogram. The initial decline in consumption, while insignificant, may be reflecting the countercyclical nature of remittances.
} 
Figure I.T. Response to One S.D. Innovation in Other Remittances
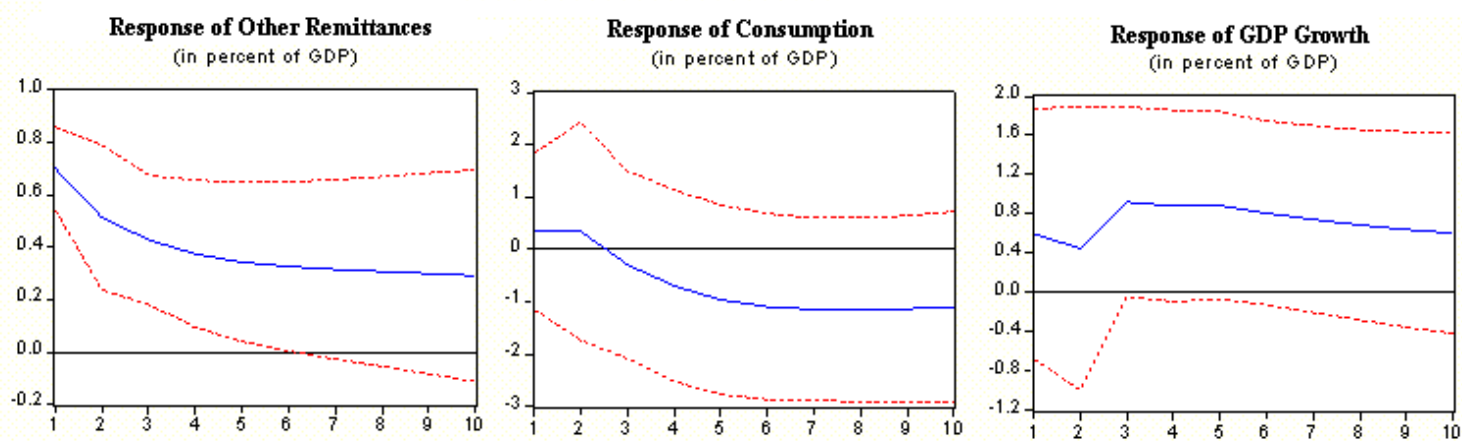

Figure I.8. Response to One S.D. Innovation in Other Remittances
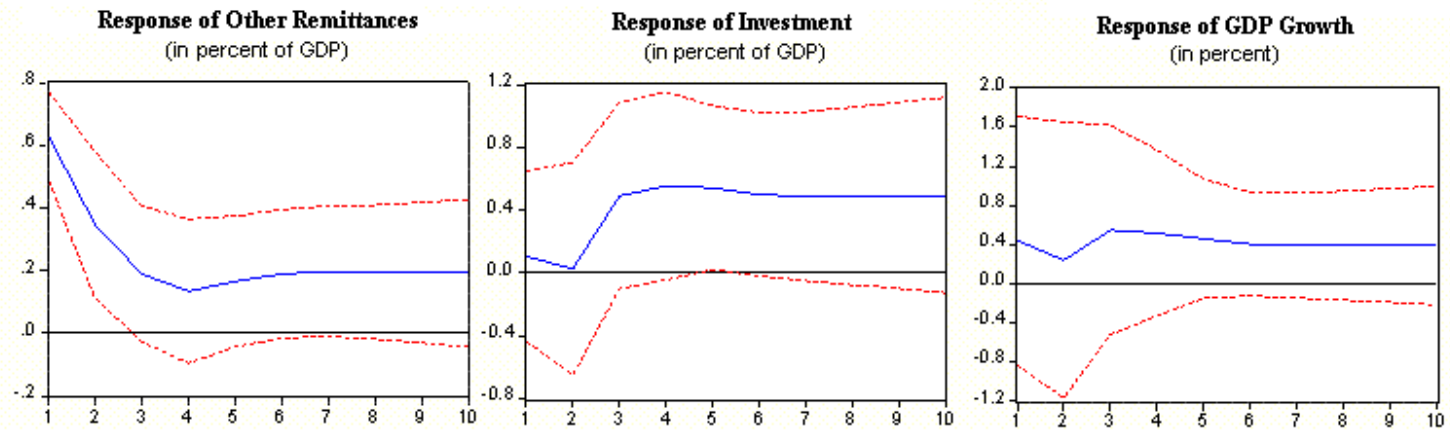

Figure I9. Response to One S.D. Inuovation in Personal Remittances

Response of Personal Remittances (in percent of GDP)

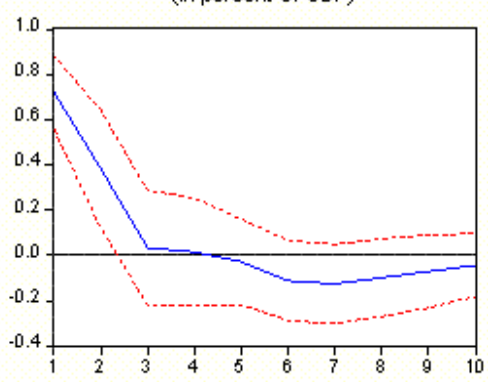

Figure I.10. Response to One S.D. Innovation in

Response of Personal Remittances (in percent of GDP)

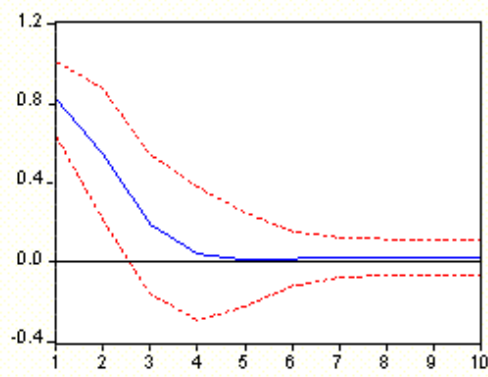

Personal Remittances

Response of Consumption (in percent of GDP)

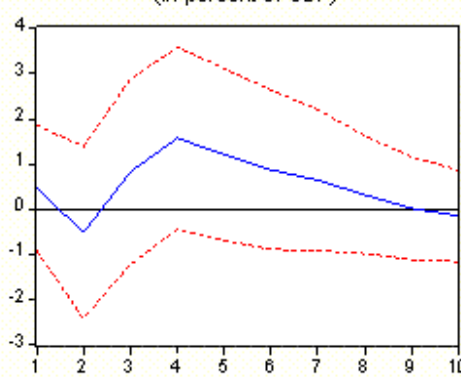

Response of Investment (in percent of GDP)

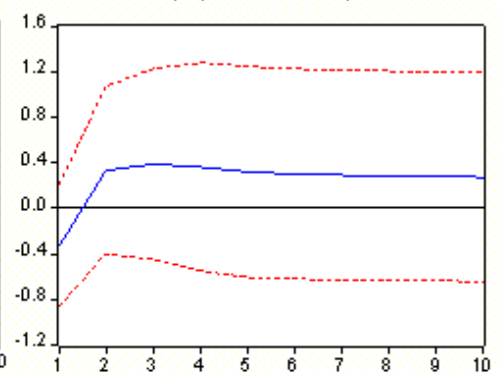

Response of GDP Growth (in percent)

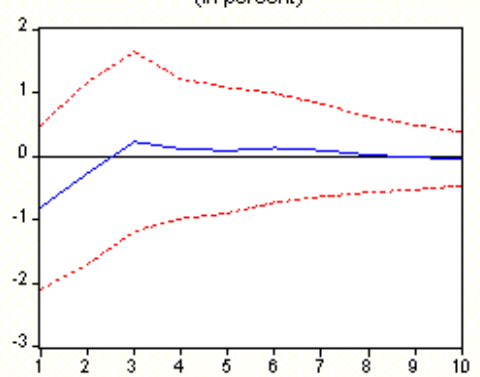


expansion induced by buoyant inflows of traditional remittances fails to stimulate economic activity, likely reflecting the countercyclical nature of remittances. Indeed, the response of GDP growth remains statistically insignificant in all periods following the shock to traditional remittances. These results are consistent with those of Roberts and Banaian (2005), who find that a US\$1 increase in remittances to Armenia leads to an increase in longrun GDP by only US\$0.20.

\section{Effects on the exchange rate}

22. Remittances are generally expected to lead to local currency appreciation. To the extent that they are sent in foreign currency and are exchanged into local currency (dram), remittances lead to an increase demand for dram and the supply of foreign currency in the foreign exchange market. In the absence of central bank interventions and other offsetting developments, this results in dram appreciation.

23. As expected, we find a strong correlation between remittances and exchange rate appreciation in Armenia (Table I.2). An increase in the ratio of total remittances to GDP is positively correlated with nominal appreciation of the Armenian dram vis-à-vis the U.S. dollar. Furthermore, causality test results indicate that both traditional remittances
Table I.2. Pairwise Granger Causality Tests 1/

\begin{tabular}{lcr}
\hline Null Hypothesis & Other remittances & $\begin{array}{r}\text { Personal } \\
\text { remittances }\end{array}$ \\
\hline Remittances cause & (Probability of rejecting the null hypothesis) \\
Consumption & 0.37 & 0.06 \\
Investment & 0.13 & 0.23 \\
GDP growth & 0.31 & 0.65 \\
USD/AMD appreciation & 0.01 & 0.02 \\
\hline
\end{tabular}

1/ Reported Granger causality tests are based on two lag specification. Alternative lag specifications produce qulitatively similar results. and other remittances are equally important for explaining the dram appreciation (Table 2).

\section{Similarly, our VAR analysis confirms that the nominal exchange rate dynamics} are strongly influenced by the behavior of remittances inflows (Figure I.11, Table I.3). A simple two-variable VAR-type model, containing total remittances and appreciation rate of Armenian dram vis-à-vis U.S. dollar, shows that a one percent of GDP increase in total remittances is statistically associated with a one percent appreciation of nominal exchange rate.

Furthermore, a variance Table I.3. Variance Decomposition 1/

\begin{tabular}{|c|c|c|c|c|}
\hline & Consumption & Investment & GDP growth 2/ & $\begin{array}{l}\text { USD/AMD } \\
\text { appreciation }\end{array}$ \\
\hline & \multicolumn{4}{|c|}{ (In percent) } \\
\hline \multicolumn{5}{|l|}{ Variance due to shocks in } \\
\hline \multicolumn{5}{|l|}{ Other remittances } \\
\hline in 4th quarter after shock & 1.6 & 9.5 & $10.5,4.2$ & 23.5 \\
\hline in 8th quarter after shock & 8.9 & 16.7 & $19.0,6.8$ & 39.9 \\
\hline \multicolumn{5}{|l|}{ Personal remittances } \\
\hline in 4th quarter after shock & 6.9 & 6.8 & $3.3,5.7$ & 30.8 \\
\hline in 8th quarter after shock & 9.4 & 6.6 & $3.1,5.7$ & 31.5 \\
\hline \multicolumn{5}{|l|}{ Total remittances } \\
\hline in 4th quarter after shock & 1.3 & 10.7 & $5.2,2.9$ & 46.0 \\
\hline in 8th quarter after shock & 1.5 & 15.7 & $10.1,5.3$ & 59.2 \\
\hline
\end{tabular}
decomposition based on the estimated model suggests that approximately 45-60 percent of variation in the exchange rate is due to volatility in remittances inflows. 
Figure I.1 1. Response to One S.D. Innovation in Total Remittances

Response of Total Remittances

(in percent of GDP)

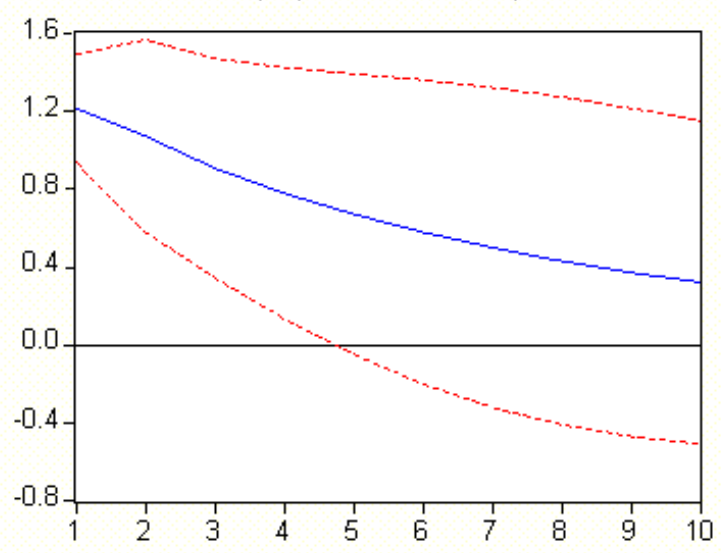

Response of USD/AMD Rate Appreciation

(in percent)

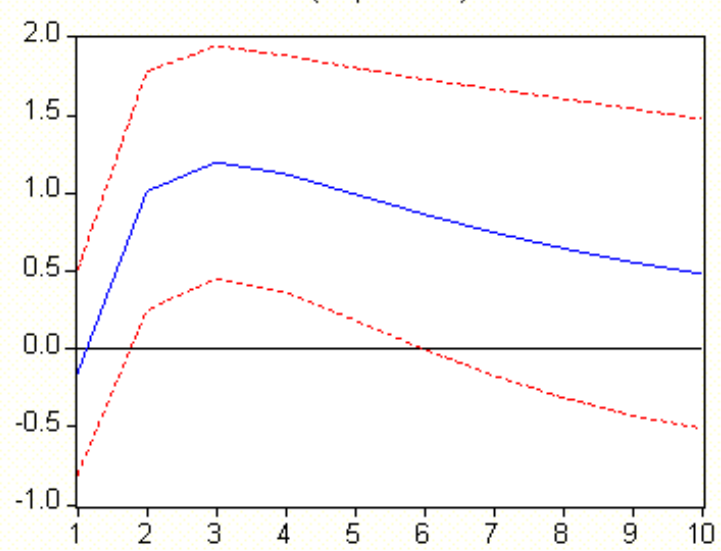

\section{E. Conclusions}

25. Remittances play a significant role in the Armenian economy. They amount to between US\$250 million and US\$1 billion per year, and constitute from 25 to 80 percent of remittances receivers' incomes. Remittances mainly come from Russia, and are strongly correlated with Russian GDP growth. Most remittances sent to Armenia are sent through the banking system, but not all of these transfers are strictly speaking "remittances." In particular, it appears that an important share of non-commercial money transfers are used for investment into real estate.

\section{The macroeconomic effects of remittances depend on the nature of the}

remittances. "Traditional remittances," which are sent by Armenians who temporarily or permanently work abroad, appear to have a positive effect on consumption, but do not appear to significantly affect GDP growth. "Other remittances," which are likely associated with real estate purchases, seem to have a positive effect on both investment and GDP growth.

\section{Our most significant finding is that both types of remittances have} unambiguously resulted in dram appreciation. Regardless of whether certain types of inflows should be classified as remittances or as foreign direct investment, they do create additional inflows of foreign currency - mainly U.S. dollars. To the extent that these dollars are eventually converted into dram, they put upward pressure on the dram/dollar exchange rate and lead to dram appreciation. 


\section{References}

Central Bank of Armenia (CBA), 2005, Survey on Dollarization (Yerevan: Central Bank of Armenia).

Central Bank of Armenia (CBA), 2006, Survey on Remittances (Yerevan: Central Bank of Armenia).

Oomes, Nienke, and Katerina Kalcheva, 2006, "Diagnosing Dutch Disease: Does Russia Have the Symptoms?," IMF Working Paper, forthcoming.

Roberts, Bryan, and King Banaian, 2005, "Remittances in Armenia: Size, Impacts, and Measures to Enhance Their Contribution to Development," presented at the Third Annual International Conference on Armenia, January 15-16 2005 Washington DC. Available via the Internet:

http://www.armpolicyresearch.org/ConferencesSeminars/ConfDocs/wp/RobertsBanai an.pdf

United Nations Technical Subgroup on the Movement of Natural Persons, 2006, "Definition of Remittances" (New York: United Nations). Available via the Internet: http://unstats.un.org/unsd/tradeserv/TSG3-Feb06/tsg0602-5.pdf 


\section{ARMenia's Low TAX ReVEnUEs: ReAsons, Recent REFORMS, AND NEXT STEPS ${ }^{19}$}

\section{A. Introduction and Summary}

28. Tax revenue reforms have been at the center of Armenia's Fund-supported program as a sufficient domestic revenue base is crucial to finance the government's expenditure priorities. Armenia's state budget has for many years benefited from large grants (1.8 percent of GDP on average over 2001-06) and concessional deficit financing (1.9 percent of GDP net). Over 2007-10, grants and net external financing are expected to decline, and to average 0.8 percent and 1.7 percent of GDP, respectively. Grants and concessional financing have created additional expenditure commitments over the next few years, and alternative sources of financing will need to be found for them.

29. Improving revenues gained momentum in 2005, contributing to a sizable rise in the tax-to-GDP ratio. The focus has been on reducing tax policy loopholes that have contributed to evasion and strengthening tax administration. The significant increase in the tax-to-GDP ratio over 2005-06 can be interpreted as a first indication that recent years' efforts are paying off. The largest increases were achieved in VAT and profits tax, each of which grew by 0.4 percent of GDP during 2005-06.

30. Nevertheless, tax revenues have remained relatively weak. With 14.7 percent of GDP in 2006, the tax-to-GDP ratio is lower than in most other CIS countries. It is also lower than the authorities' poverty reduction strategy target of 16.2 percent of GDP for 2006 and than the level of 2000 .

31. The relatively weak revenue performance is rooted mainly in tax exemptions and tax evasion. The VAT and the profits and income taxes account for the largest shortcomings relative to their potential. The VAT has been undermined by numerous exemptions from taxation at the border, combined with widespread evasion of domestic VAT payment; the profits tax suffers from tax holidays for foreign investors which have contributed to abuse and reporting of tax losses that are difficult to reconcile with strong economic growth; and the income tax is reduced by customary underreporting of wages. Comparing the current revenue from these three taxes with other transition countries and with the potential implied by national accounts data suggests a large additional revenue potential at the current tax rates.

32. Moving forward, tax policy reforms should concentrate on reducing exemptions, while tax administration should focus on tax audits to reduce tax evasion. In tax policy, the priorities are: phasing out most exemptions from VAT payment at the border, not

\footnotetext{
${ }^{19}$ Prepared by David Hauner (FAD).
} 
renewing the profits tax exemptions for foreign investors, and bringing large-scale producers in the agricultural sectors and those subject only to presumptive taxes into the regular tax regime. In tax administration, strengthening audits and crosschecks will be essential to reduce the underreporting of VAT and wages and the declaration of tax losses by profitable enterprises, as well as to stem the accumulation of further tax arrears. To focus reforms over the next few years, a comprehensive tax administration modernization program is needed. In the absence of significant improvements in administration, there is the risk that the recent revenue gains could taper off, or that ad hoc measures to raise revenues could gain ground.

\section{B. Reasons for Armenia's Low Tax Revenue}

\section{Armenia relies heavily on indirect taxes (VAT, excises, and customs duties)} which contributed 9.0 percent of GDP, or 63 percent of total tax revenue in 2005 (Table II.1). Direct taxes, primarily the personal income tax and the profits tax, contribute relatively little revenues; together with the presumptive taxes on a number of economic activities that are particularly prone to evasion (such as restaurants) and the simplified tax for small firms, they amount to 4.2 percent of GDP or 29 percent of total revenue. Wealth taxes (the land and property taxes) are negligible, while other taxes (including stamp duties) contribute 1.2 percent of GDP or 8.3 percent of the total.

Table II.1. Armenia-Tax Revenue, 2005

\begin{tabular}{lcc}
\hline \multicolumn{1}{c}{ Tax } & In Percent of GDP & In Percent of Total \\
\hline Total & 14.4 & 100.0 \\
VAT & 6.6 & 45.7 \\
Excises & 1.7 & 12.0 \\
Customs duties & 0.7 & 5.1 \\
Income tax & 1.2 & 8.3 \\
Profits tax & 2.1 & 14.5 \\
Presumptive tax & 0.6 & 4.0 \\
Simplified tax & 0.3 & 2.1 \\
Land tax & 0.0 & 0.0 \\
Property tax & 0.0 & 0.0 \\
Other taxes & 1.2 & 8.3 \\
\hline
\end{tabular}

Source: Armenian authorities.

34. Weaknesses in VAT and income taxes explain most of the gap in the tax-to-GDP ratio between Armenia and other transition countries. Figure II.1 shows revenues by tax relative to GDP for 10 CIS and Eastern European countries. Taxes on goods and services (VAT, excises) and taxes on income, profits, and capital gains contribute the main share of revenue in all countries. An analysis of the weaknesses of Armenia's tax performance will thus have to focus on these two types of taxes that carry most of the potential. Armenia ranks very low among transition economies for both group of taxes: revenues from taxes on goods and services (VAT, excises) rank third from the bottom, about 3 percent of GDP lower than in most other countries; even starker, revenues from taxes on income, profits, and capital 
gains ranks at the bottom, about 1 percent of GDP lower than in the next-highest group (Azerbaijan, Bulgaria, Romania), and 4-6 percent of GDP lower than in Estonia, Lithuania, Russia, or Ukraine. These gaps are likely to be mostly due to exemptions, loopholes, and weak administration, as Armenia's tax rates are broadly in line with those in the other countries. ${ }^{20}$ In sum, comparison with a group of other transition economies suggests an additional tax potential of at least about 3 percent of GDP in VAT and 1 percent of GDP in income taxes.

Figure II.1. Revenue by Tax in Selected Transition Countries, 2005 (In percent of GDP)

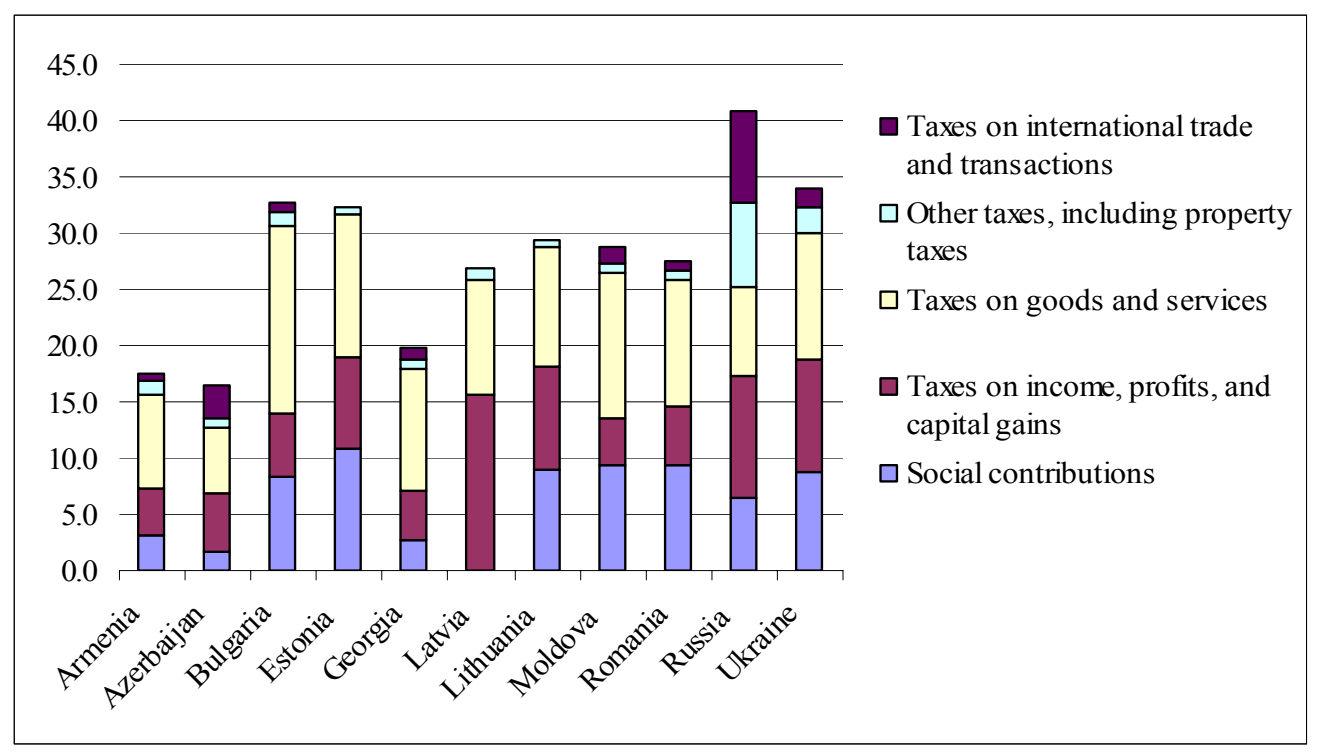

Sources: Country authorities; and Fund staff estimates.

\section{Total tax revenues in percent of GDP remain below 1999-2001 levels. Figure} II. 2 shows the composition of tax revenues in Armenia over 1996-2006. VAT revenue has remained highly stable relative to GDP since 1999, although it is partly overstated by the accumulation of VAT refund arrears during this period. Excises have fallen by 0.9 percent of GDP since 2002, due to the appreciation of the dram, as several excises were denominated in US dollars; a change in the denomination to dram and an increase in rates in 2005 should have brought revenue back to its original level in 2006, but growth in excises has remained relatively weak. While the remaining taxes have been stable since 1999 as well, it is the income and profits taxes that have contributed most to the decline in overall tax revenue since then: from 1999 to 2003 , they fell by 1.6 percent of GDP, although this is partly

\footnotetext{
${ }^{20}$ Armenia and most of the other transition economies in the sample have a standard VAT rate of 20 percent (and some have a lower rate), but Armenia's VAT productivity (that is [VAT revenue/consumption] / rate) is lower than in most peer countries. However, Armenia's income and profit tax rates are relatively low.
} 
explained by one-off effects in 1999. However, in 2005-06, the tax-to-GDP ratio rose by 1.0 percentage points of GDP, excluding a negative one-off effect in excises.

Figure II.2. Revenue by Tax, 1996-2006 (In percent of GDP)

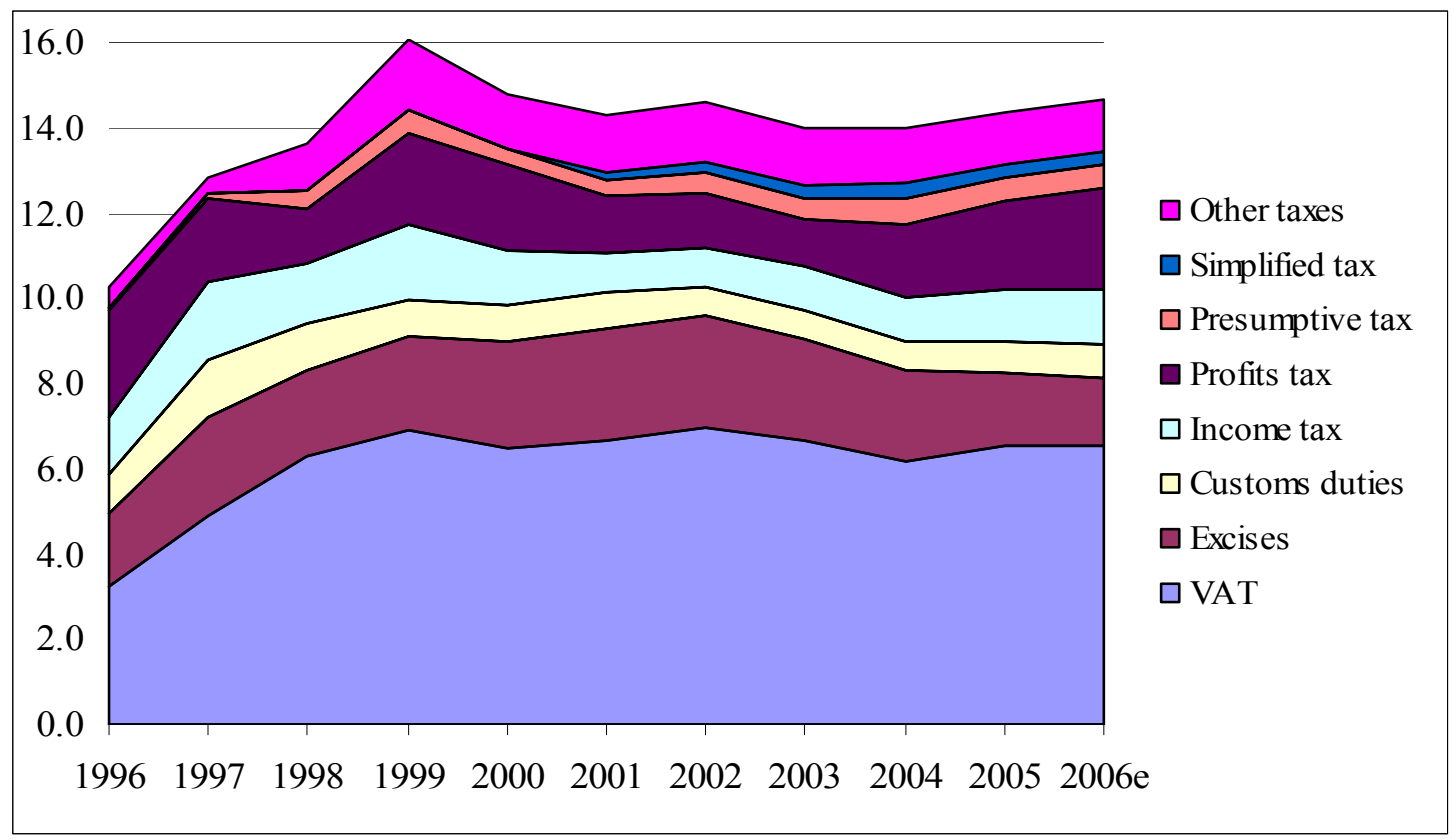

Sources: Armenian authorities; and Fund staff estimates.

36. The VAT falls short of its potential due to the large number of exemptions from VAT payment at the border. While, in principle, these exemptions should shift the first point of collection of VAT inland, in practice it introduces a loophole due to the large number of businesses operating outside the VAT base and the possibility that the importer sells the good for final consumption without charging VAT or underdeclaring the taxable sales value. The fact that most VAT that is not collected at the border is lost is highlighted by the unusually high share of total VAT revenue that is collected at importation: at 69 percent, it was the highest among a sample of transition countries shown in Table II. $2{ }^{21}$ also for excises, as well as for total tax revenue, the share of collection at the border is the highest among the transition economies in the sample. Under the extreme assumption that no VAT is currently collected inland on the one-third of imports value that is exempted from taxation at the border, eliminating all exemptions could yield additional revenue of up to 2 percent of GDP, given that VAT revenue collected at the border was 4.2 percent of GDP in 2005.

\footnotetext{
${ }^{21}$ Some of these differences may be due to the various national institutional arrangements.
} 
Table II.2. Share of Customs Agencies in Revenue, 2004

\begin{tabular}{lccccccc}
\hline & Armenia & Albania & Azerbaijan & Georgia & Hungary & Russia & Ukraine \\
\hline Total tax revenue & 44.8 & 46.0 & 23.7 & 31.9 & 29.0 & 43.1 & 37.0 \\
Gross VAT revenue & 68.5 & 65.2 & 37.0 & 58.7 & 25.2 & 30.0 & 48.9 \\
Excise revenue & 65.2 & 56.0 & 0.0 & 50.0 & $\ldots$ & 3.9 & 6.3 \\
\hline
\end{tabular}

Sources: Country authorities; and Fund staff estimates.

37. The decline in the profits tax was partly due to the introduction of tax incentives for foreign investors, but mostly due to evasion. In 1998, a tax holiday for foreign investors was introduced and depreciation was accelerated. This tax policy change is widely perceived to explain most of the decline in the GDP ratio. However, there are at least three reasons to believe that most of the loss is explained by evasion and weak administration that have prevented tax revenue from keeping-up with strong buoyant economic growth: first, profit tax revenues collected from companies with foreign participation amounted to only 0.5 percent of GDP in 1999, which suggests that the profit tax-to-GDP ratio could not have declined by more than that as a result of the tax holidays, unless the share of profits of foreign-owned firms in total profits has dramatically increased; second, the ratio of profits tax to GDP has continued to decline several years after the introduction of the tax holidays, as Figure II.3 shows; third, despite strong macroeconomic growth, a large number of the leading companies continues to report losses for tax purposes, not all which can be explained by accelerated depreciation. These three observations suggest that the weak profits tax revenues has been the result of evasion through the shift into foreign investment vehicles set up for tax purposes and underreporting of profits. Both are partly the result of weaknesses in administration, primarily in the area of tax audits. Moreover, the introduction of the simplified tax in 2000 is likely to have created multiple opportunities for tax evasion by smaller taxpayers. In sum, these considerations suggest a large shortfall of profit tax revenues relative to their theoretical potential: based on national accounts data on corporate profits, a 20 percent profits tax should yield about 6 percent of GDP, implying an extra potential of 3 percent of GDP compared to the current total revenue of the profits, presumptive, and simplified taxes.

\section{The decline in the income tax is also likely to be mostly due to tax evasion.}

Revenues have declined by 0.6 percent of GDP since 1999 . While the rate schedule was changed in 2001, this has reduced revenues by only 0.14 percent of GDP. Rather, collection efficiency is likely to be the main explanation for the decline, especially through underdeclaration of wages by employers, partly driven by "bracket creep" in the face of strong nominal income growth and in the absence of rate bracket indexation. Based on national accounts data and assuming an informal sector share of 30 percent of GDP, wages should be more than twice as large as currently reported. This suggests an additional revenue potential in the order of 1 percent of GDP from the formal sector alone, without tax policy changes. 
Figure II.3. Change in Ratio of Individual Taxes to GDP, 2000-06

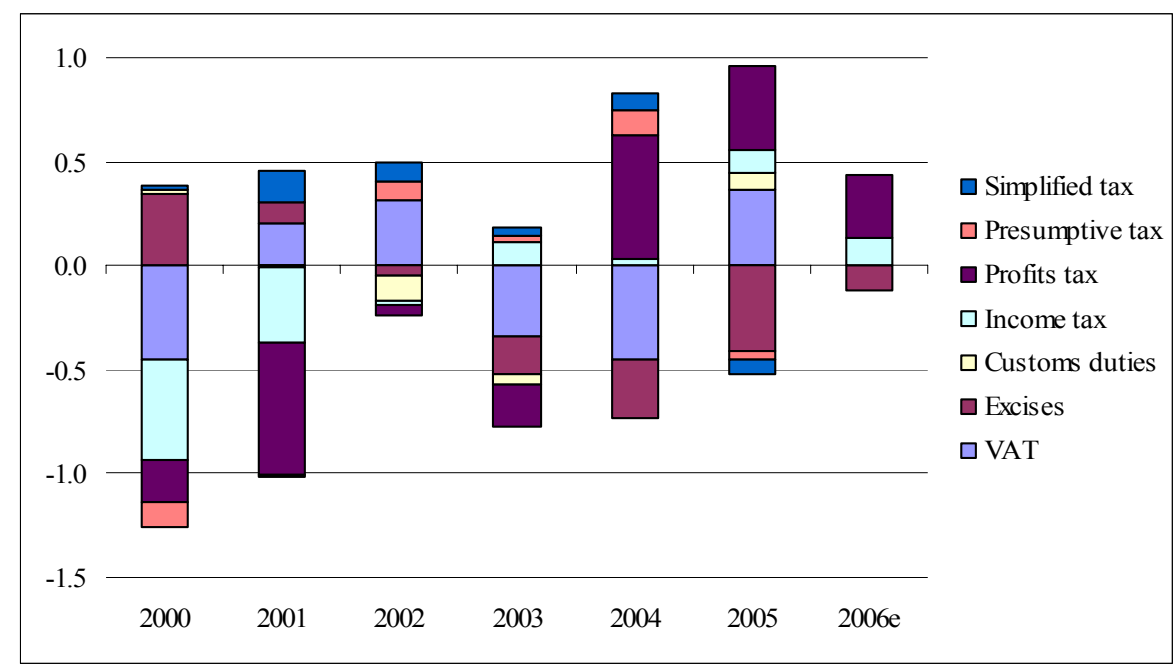

Sources: Armenian authorities; and Fund staff estimates.

Note: The bars show the combined effect of the taxes; for example, in 2005 four taxes together raised the tax/GDP ratio by about 1 percentage point, while three other taxes together reduced it by about 0.5 percentage points.

\section{Shortcomings in tax administration probably account for a large part of the} shortfall in revenues relative to potential. Weak tax administration is also likely to account for low revenue buoyancy, that is, the elasticity of revenue growth to the growth of the tax base. Figure II. 4 shows the contribution of the growth of the tax base to the observed nominal increase in revenue, with the difference to the actual revenue increase due to tax administration. ${ }^{22}$ To account for the potential impact of growth in little taxed sectors, the tax base contribution is estimated both by overall nominal GDP growth (the first column for each year in Figure II.4 below) and by separate tax bases for VAT, the profit tax, ${ }^{23}$ and customs duties (the second column). Tax administration contributed negatively in 2003 and virtually nothing in $2004,{ }^{24}$ in both years, the difference between the estimates based on overall GDP and separate tax bases was negligible. However, in 2005-06, the contribution of tax policy and administration became substantially positive. This suggests that the reforms of recent years are beginning to yield results.

\footnotetext{
${ }^{22}$ The expected nominal increase in revenues is the growth rate of the tax base times revenue in the preceding period. If, such as in 2003, the actual increase in revenues is smaller than this expected increase, the elasticity of revenues to base is below unity, and the ratio of revenues to tax base falls. In the absence of changes in tax policy, such a shortfall is due to tax administration not keeping up with the tax base growth.

${ }^{23}$ Excluding agriculture and construction.

${ }^{24}$ There was no reduction to revenues from tax policy during this period, so all the residual is accounted for by tax administration. A negative contribution implies that revenue should have grown faster than it actually did.
} 
Figure II.4. Estimated Contributions to Change in Total Tax Revenue, 2003-06 (In millions of drams)

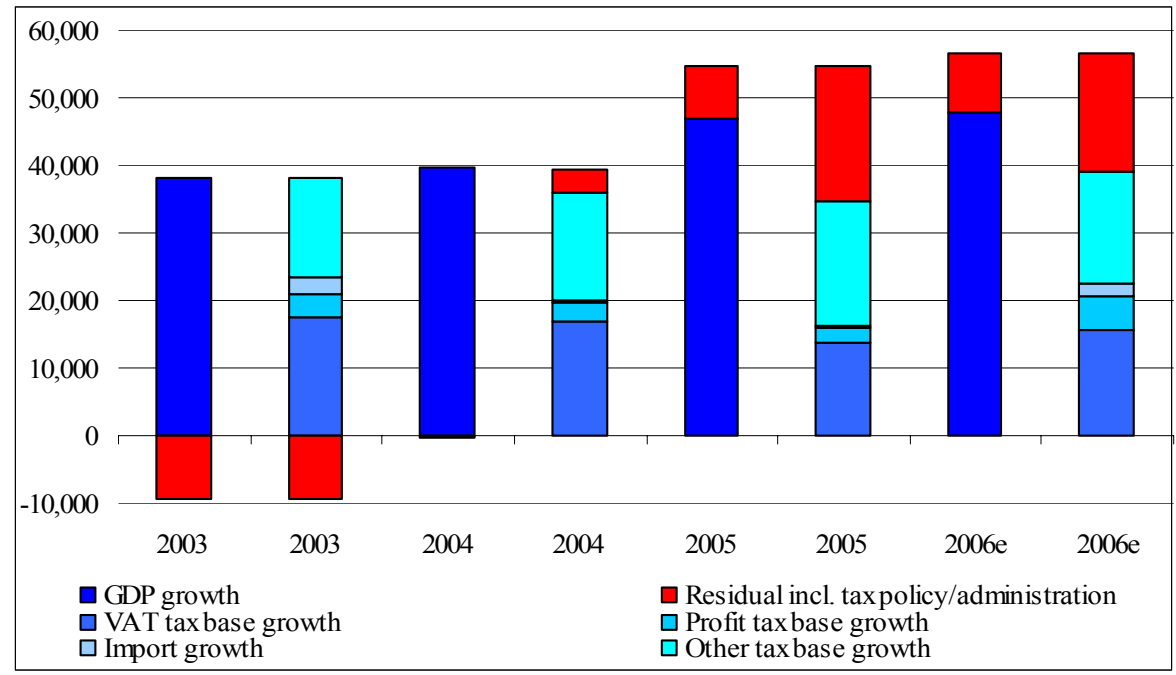

Source: Fund staff estimates.

Note: For each year, the left bar shows the expected increase in tax revenue according to GDP growth, and the right bar the expected increase according to the growth of the bases of the individual taxes. In both cases, the difference between the expected and the actual increase in tax revenue is due to tax policy and administration.

\section{Recent Reforms}

40. Improving revenue performance has long been a priority area for structural reforms, but has gained additional momentum in 2005 . The fact that many large profitable enterprises pay little taxes has gained increasing attention in the public and political spheres. The introduction of a quarterly publication of the 300 largest taxpayers in the newspapers beginning in April 2005 has contributed to this development. In May 2005, the government approved a 2005-06 action plan for reforms in tax policy and tax and customs administration. The plan's tax policy reforms focused on broadening the tax base through the reduction of exemptions and loopholes (for example, in the areas of VAT exemptions at the border, profit tax holidays, agriculture, and the simplified and presumptive taxes). Tax and customs administration reforms focus on improving tax compliance (particularly by large enterprises) through audits and reducing the accrual of tax arrears.

\section{In the area of tax policy, a number of reforms have been achieved in recent} years. Most importantly, in 2006 many exemptions from VAT payment at the border were abolished and the VAT regime was tightened to reduce evasion in the construction sector. Moreover, access to the simplified tax was progressively reduced to return taxpayers to the regular tax regime and a minimum profit tax was introduced to curb the undermining of profit tax collections by evasion schemes. In addition, the profit tax exemption for foreign 
exchange gains was eliminated, the profit tax loss carry-forward reduced, and the property tax base broadened.

42. Progress in tax administration reform has also picked up. This included the establishment of a dedicated tax arrears collection function, of a large taxpayers unit that also includes the central audit department, and of an internal audit unit, longer time limits for the audit of large enterprises, a code of conduct for tax officials, and moving the VAT refund process and audit selection towards risk-based approaches. Sanctions for providing false documentation to revenue agencies were increased and the audit powers of the State Tax Service (STS) were extended. To better cover the buoyant mining sector, a special large taxpayer unit was set up. Moreover, a 2006-08 IT strategy and an acquisition plan for the STS were finalized, first steps to systematically address impediments to the next generation of tax administration reforms.

43. There has also been some progress in customs administration reforms. The main recent developments were the revision of customs legislation to include valuation principles in conformity with World Trade Organization standards and the installation of the ASYCUDA system in all customs houses. However, custom declarations remain complex and progress in moving to importer self assessment has been slower-than-expected; the implementation of a post clearance verification program has been delayed; and enforcement of a new code of conduct for customs officials is limited.

44. A number of further reforms are envisaged for the remainder of $\mathbf{2 0 0 6}$ and early 2007. In tax policy, creation of a unified tax code should improve the consistency of the tax system, and the indexation of the presumptive tax rates should help preserve safeguard against inflation. In tax administration, a unified computer network linking all inspectorates of the STS and an electronic risk-based selection system for VAT cross-checks, audits, and refunds are to be established during 2007. This would be a major step forward for tax administration in Armenia, as many improvements hinge on the removal of IT bottlenecks. In customs administration, an intelligence-based system for risk management is to be established.

\section{Next Steps}

45. Moving forward, tax policy reforms should focus on limiting loopholes in the tax system to reduce evasion and make the system more equitable. Priority steps include reducing exemptions from VAT payment at importation; further narrowing the access to the simplified tax; and bringing large-scale operations from the presumptive to the normal tax regime. It will also be important that the exemptions for foreign investors indeed lapse in 2008 as envisaged at their inception, and the agricultural sector is brought into the tax system by 2009, in line with Armenia's WTO agreement. 
46. Reducing exemptions from VAT payment at the border is crucial. The reason for their introduction was to provide cash-flow relief to importers of intermediate and capital goods in the face of shortcomings in the VAT refund system. The 2005 introduction of the capital deferral system solves this problem by deferring taxation but recording the goods for VAT purposes. Any capital goods that remain tax exempt should be moved to the capital deferral system. Moreover, the VAT refund system, whose deficiencies previously were also a reason for VAT exemptions, has been significantly improved in recent years, as documented by stabilization of the stock of VAT refund arrears in 2005.

47. To raise profits tax revenue, the tax holiday for foreign investors should be abolished, access to the simplified tax should be narrowed, and tax audits should be improved. The standard profits tax is favorable for investors: its rate of 20 percent is comparatively low by international standards, and the depreciation schedule and the provision on loss carry-forward are generous. In this context, the additional positive growth impact of the tax holiday is likely to be limited, while it has implied a significant revenue loss which has been exacerbated by tax evasion schemes. To reduce evasion, not least through the declaration of losses for tax purposes by profitable companies, tax audits should be improved by the introduction of full-fledged risk-based selection criteria and better training for auditors.

48. Activities that are not particularly difficult to tax, as well as large-scale businesses should be moved from the presumptive to the regular VAT and profits tax regime. This concerns in particular imported petrol and diesel fuel and natural gas, given the relative ease in valuation and seemingly limited risk of smuggling. Currently, any profits tax beyond the presumptive tax liability is lost for businesses in these areas. To stem the danger of revenue loss, the minimum of the normal profits tax and the respective presumptive tax could apply. In the medium term, most (if not all) remaining activities should be moved from the presumptive to the regular tax regime.

49. The construction sector, which is particularly prone to evasion, should be taxed more, and large-scale agriculture should be brought into the regular VAT and profit tax regime. The contribution of the fast-growing construction sector should be increased, possibly through the introduction of a presumptive tax. Moreover, it is important to bring large-scale agriculture into the tax system by 2009. Most small farmers are below the income tax and VAT thresholds and will thus remain unaffected.

50. These steps would not only raise revenues, but also make the tax system more equitable. Currently, the overwhelming share of taxes on goods and services adds a regressive element to the tax system, as lower income groups consume a larger part of their income. Moreover, the property and land taxes could introduce more progression into the tax system if true market values were applied to calculate their base. 
51. In tax administration, the focus should be on tax audits and tax arrears

collection. Specifically, the move towards risk-based selection mechanisms and crosschecking based on modern information systems will be central to the next step in upgrading tax administration. In addition, the audit powers of the tax agency and the capacity of the large taxpayers unit will need to be strengthened further, as well as the enforcement powers of the tax agency in tax arrears collection. Upgrading the IT capacity, for example, by establishing a network linking headquarters and the branches, is crucial for improving audits and crosschecks. 


\section{ARmenia's Financial System: \\ WHY IS IT SMALL AND WHAT REFORMS ARE NEEDED? ${ }^{25}$}

\section{A. Overview}

52. This chapter describes recent developments in the Armenian financial system, provides an overview of the roots of financial sector underdevelopment, and discusses measures to foster financial deepening in the medium term. It finds that financial sector development appears to be accelerating lately, and concludes that — while important risks remain - both the financial system and the regulatory and supervisory framework are increasingly well prepared to manage rapid credit growth and increasing competition, and provide a wider range of financial services.

53. Armenia has experienced an impressive economic expansion, with double-digit growth rates since 2001. Until recently, however, rapid income growth has not been accompanied by a significant development of the financial sector. Financial intermediation through banks is small, while the nonbank financial sector and capital markets are still in their infancy. Financial depth as measured by monetization (M2X/GDP) is lower than in other CIS countries. ${ }^{26}$

Figure III.1. Financial Depth: M2X/GDP

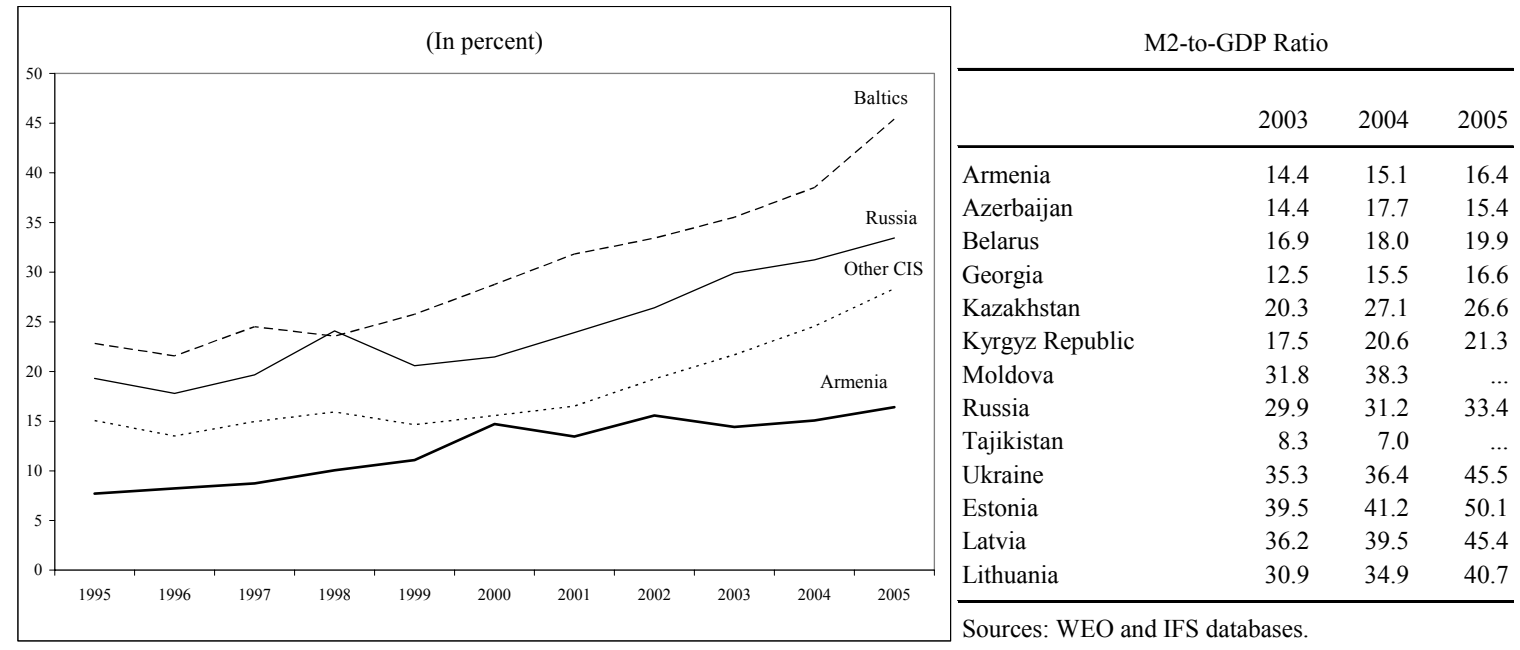

\footnotetext{
25 Prepared by Holger Floerkemeier.

${ }^{26}$ Actual monetization, however, may be much higher due to substantial cash dollarization. Foreign currency cash holdings are estimated to exceed US\$1 billion, an amount far higher than the M2X measure (broad money including foreign currency deposits).
} 
54. Given the well-established significance of financial development for economic growth, deepening financial intermediation and improving financial market efficiency will be important for sustaining the current growth momentum in Armenia over the medium term. A sophisticated financial system would promote future growth by (i) efficiently mobilizing and pooling savings; (ii) channeling investments towards activities with high returns; (iii) facilitating risk management by providing risk diversification services; and (iv) exerting corporate governance through monitoring borrowers (Levine, Loayza, and Beck, 2000).

\section{B. Size, Structure and Stability of the Financial Sector}

55. The depth of financial intermediation, as measured by financial sector assets to GDP, is still low at around 20 percent and is considerably below the CIS average of more than 30 percent. Armenia also lags other CIS and Baltic countries in the development of private sector credit and bank deposits.

Figure III.2. Total Bank Assets/GDP

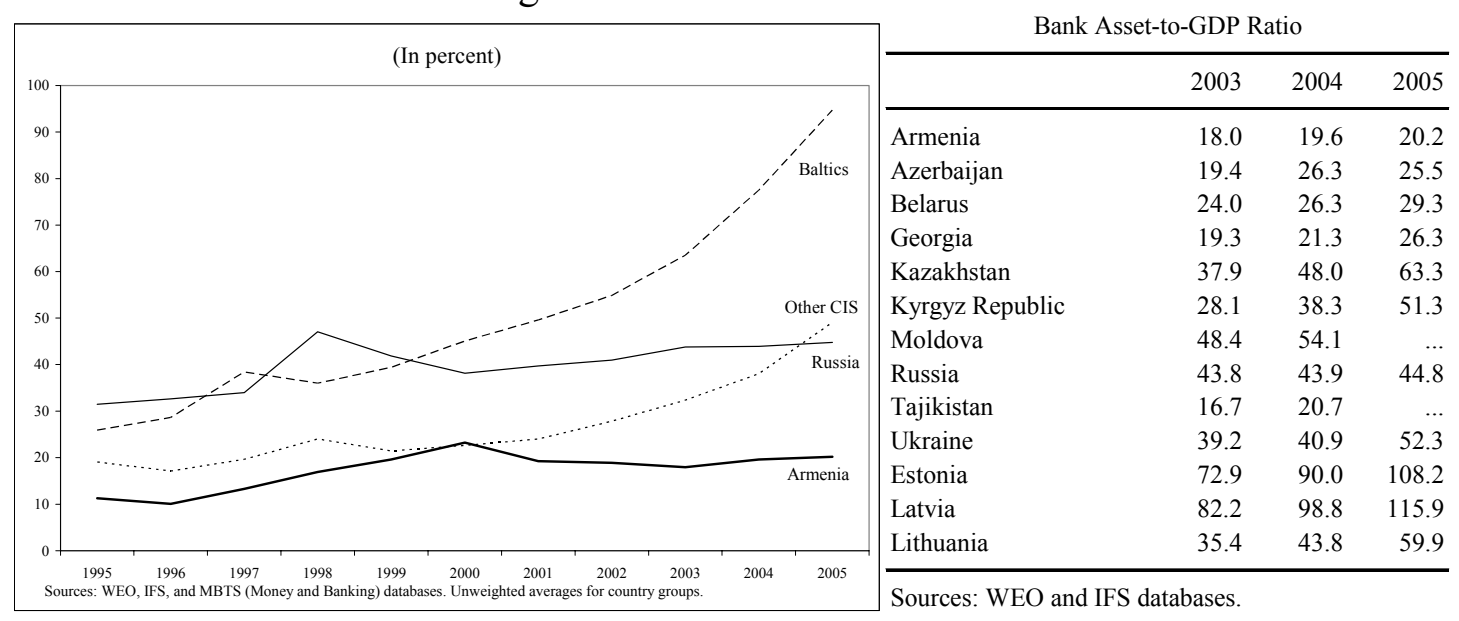

Figure III.3. Bank Credit to Private Sector

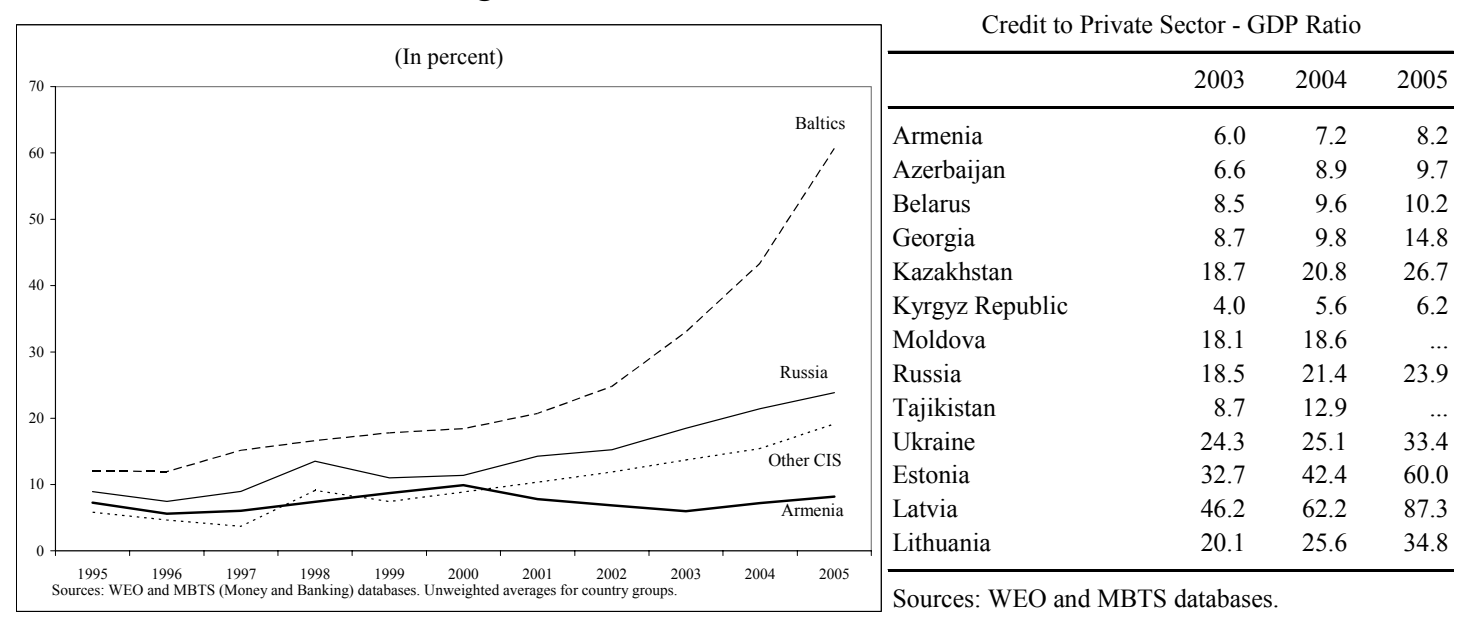


Figure III.4. Bank Deposits/GDP

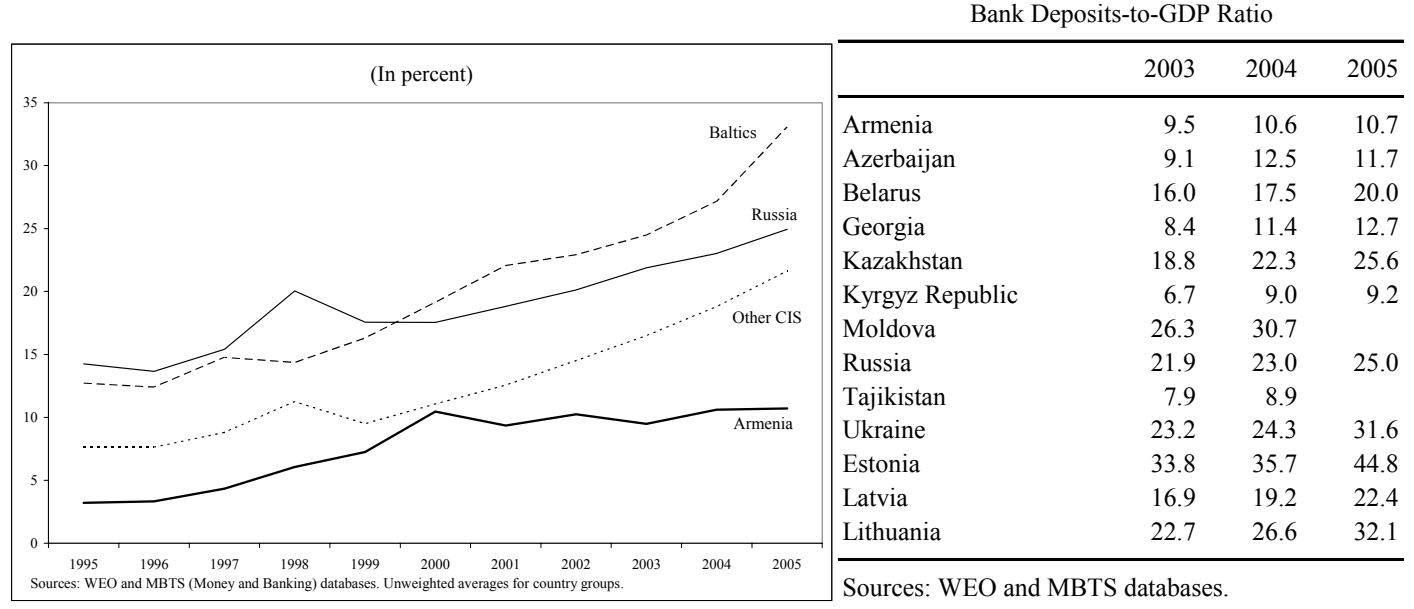

56. The preference for liquid assets is high. A comparatively large share of bank assets consists of cash, interbank balances, and investments in securities, while the share of loans in total bank assets is small by international standards. Although a trend towards higher use of domestic currency has emerged, the economy is still heavily dollarized, relying on foreign currency cash for transactions. The majority of loans and deposits are still denominated in foreign currency, which could trigger currency mismatches for commercial banks and impedes the central bank's capability to conduct effective monetary policy. Banks' capacity to attract deposits has been traditionally low, indicating little provision of financial services in the form of payment services and saving vehicles.

Figure III.5. Liquidity and Dollarization Indicators

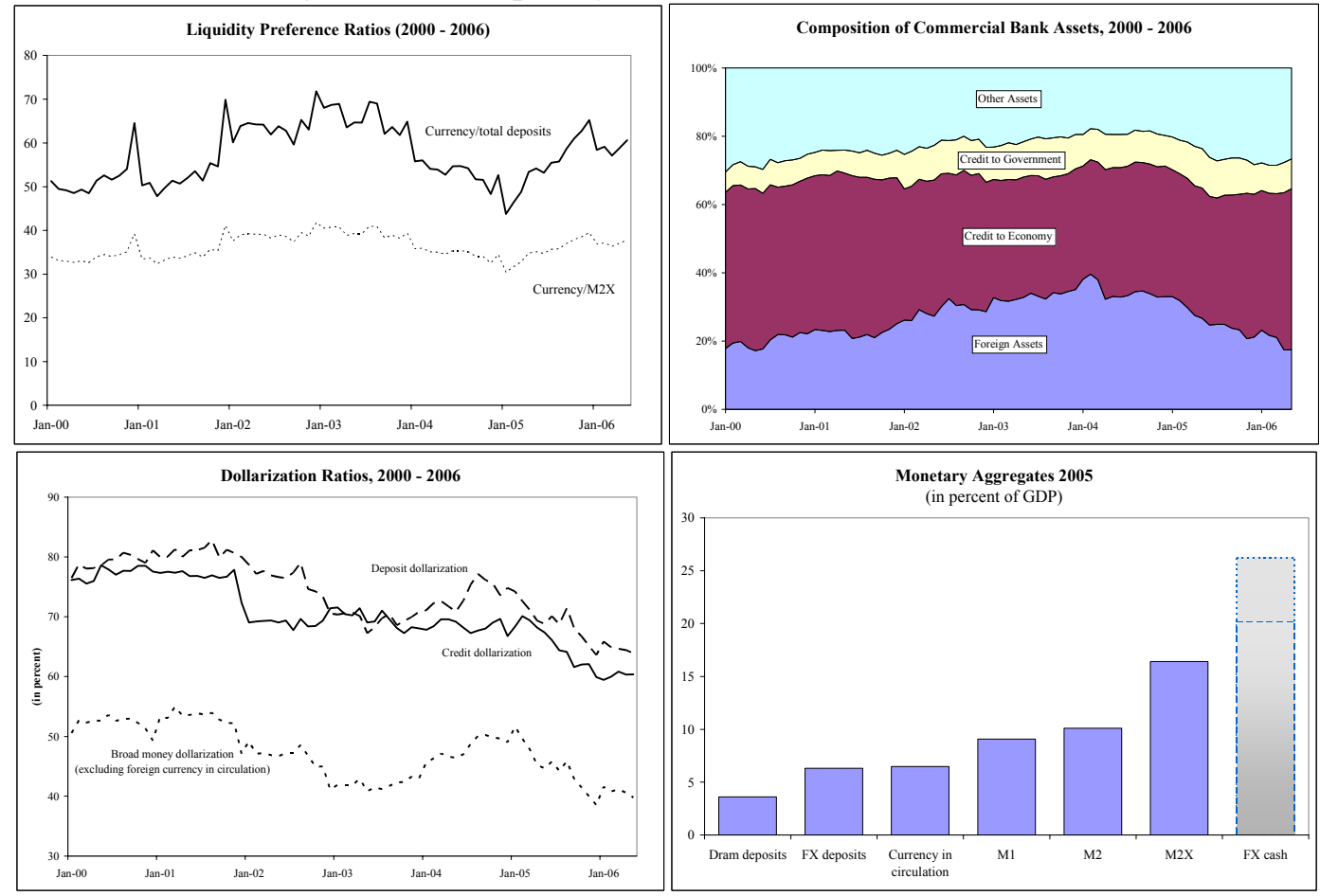

Source: WEO and MBTS databases. 
57. The banking sector is the central pillar of financial intermediation, with banking sector assets accounting for about 97 percent of total financial sector assets. There are currently 21 banks, all privately owned. ${ }^{27}$ Foreign participation in the banking system increased following the removal of limits on foreign ownership in the mid-1990s. However, with one key exception, foreign investors were mainly Armenian expatriate individuals without the benefit of foreign banking expertise. Recently, some banks from other CIS countries have entered the Armenian market by taking over existing local banks.

58. Concentration in the banking sector is relatively low. Herfindahl-Hirshman Indices (HHI) indicate low concentration of total bank assets and credit, while deposit concentration is moderate. ${ }^{28}$ The higher concentration indicators for bank deposits are mainly due to the dominant position of the only international bank in demand deposits, with a market share in this segment of more than 50 percent.

Figure III.6. Banking System Concentration
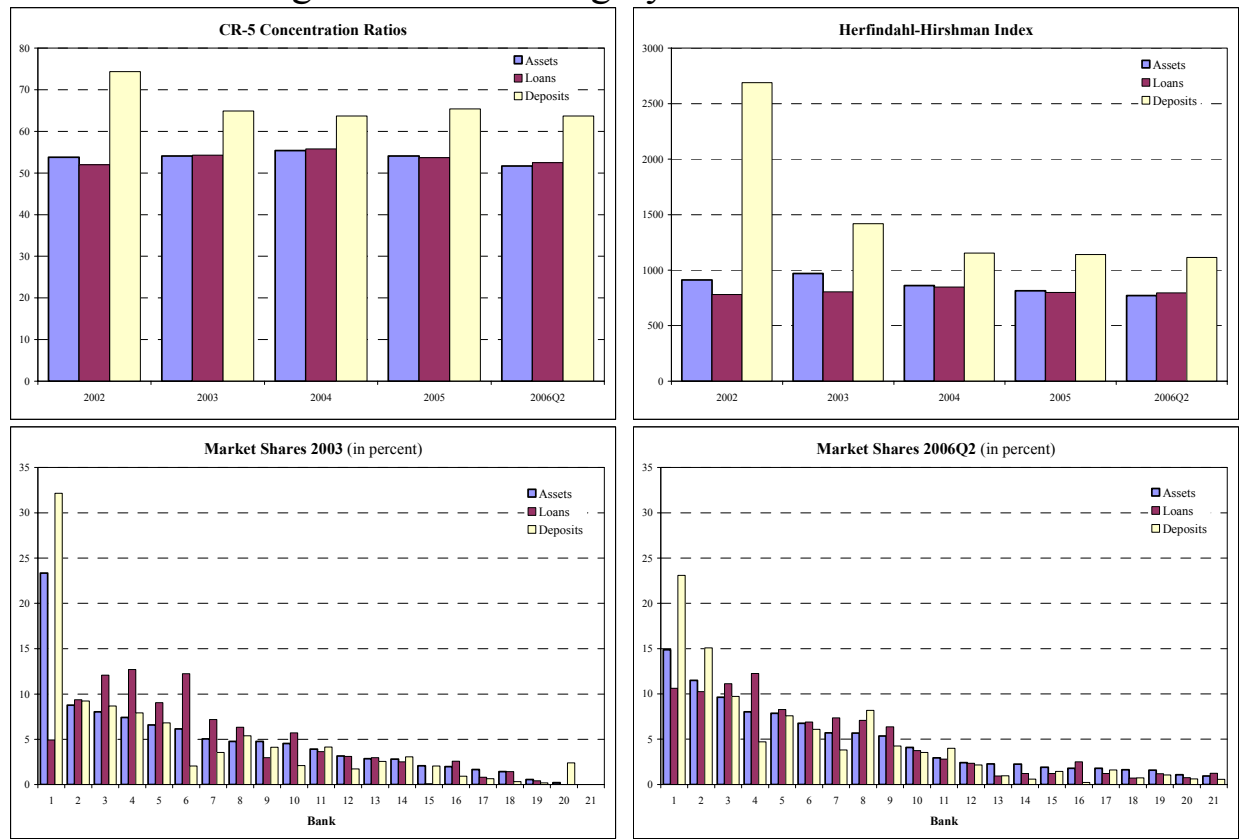

Source: ARKA.

\footnotetext{
${ }^{27}$ The banking system has consolidated in recent years. The gradual tightening of prudential regulations and a serious banking crisis between 2000 and 2002 contributed to a reduction of the number of banks from 74 in 1994 to 21 currently.

${ }^{28}$ The Herfindahl-Hirschman Index is defined as the sum of squared market shares of all firms competing in a market. The HHI takes into account the relative size and distribution of the firms and increases both as the number of firms in the market decreases and as the disparity in size between those firms increases. The U.S. Department of Justice considers markets in which the HHI is between 1000 and 1800 points to be moderately concentrated, and those in which the HHI is in excess of 1800 points concentrated.
} 
59. Lending-deposit spreads, measured as the difference between average domestic currency lending and deposit rates, remain high. They exceed 10 percent and are well above those in most other CIS countries. Continued high spreads, associated with high real lending rates and collateral requirements, are particularly harmful for small and medium-sized enterprises.

Figure III.7. Lending-Deposit Spreads

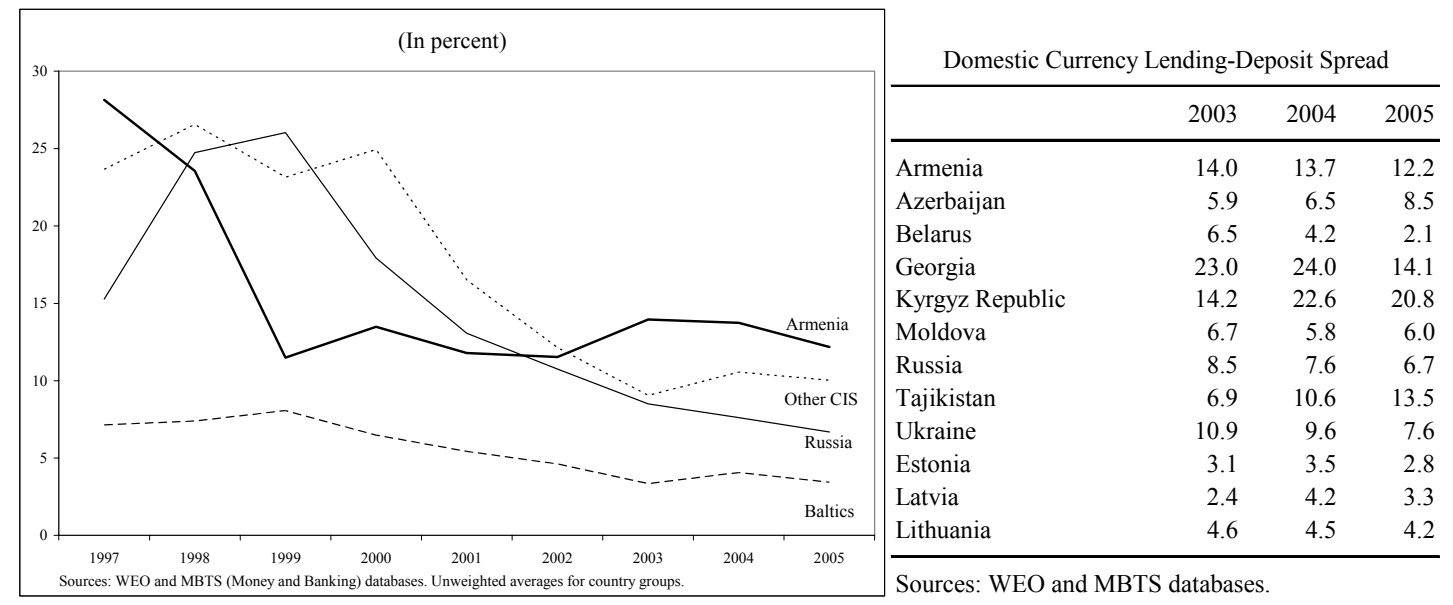

60. Despite the sizable lending-deposit spreads, transformation ratios are high on average. However, this appears to be less an indication of banks' success in efficiently intermediating funds between savers and investors, but rather of the continued difficulty many banks face to attract deposits, owing to low trust in the banking system and the widespread use of cash, mainly related to the sizable shadow economy. Transformation rates have generally increased in recent years. At the same time, they continue to differ widely across banks, indicating a high level of market segmentation.

Figure III.8. Intermediation Indicators
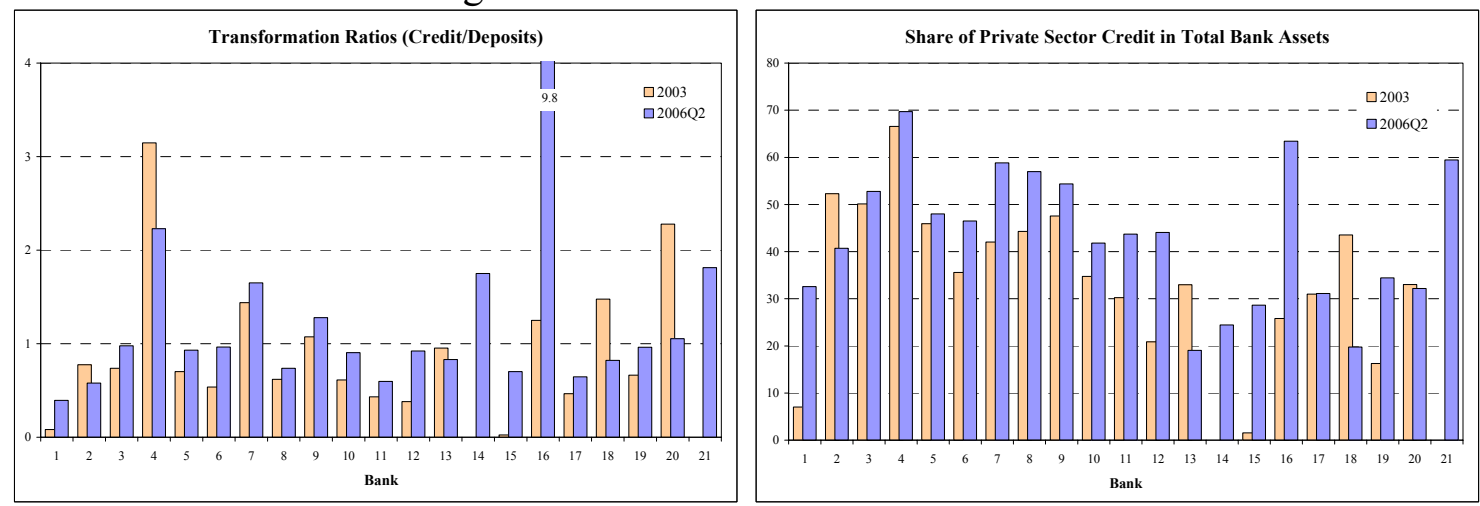

Source: ARKA.

61. The structure of bank credits and deposits is gradually changing with respect to the customer base, currency denomination, and maturities: Corporate loans still account for the majority of private sector credit, but the market share of loans to individuals has been 
increasing steadily. Growth of mortgage lending has taken off lately, although from a low base. ${ }^{29}$ Aided both by efforts of the central bank to promote the use of domestic currency and the continuing appreciation of the dram, the shares of foreign exchange denominated loans and deposits are on the decline. Credit maturities are lengthening. The share of long-term loans (with maturities of more than one year) has increased from less than 45 percent in 2002 to 65 percent in mid-2006.

Figure III.9. Structure of Bank Credits and Deposits
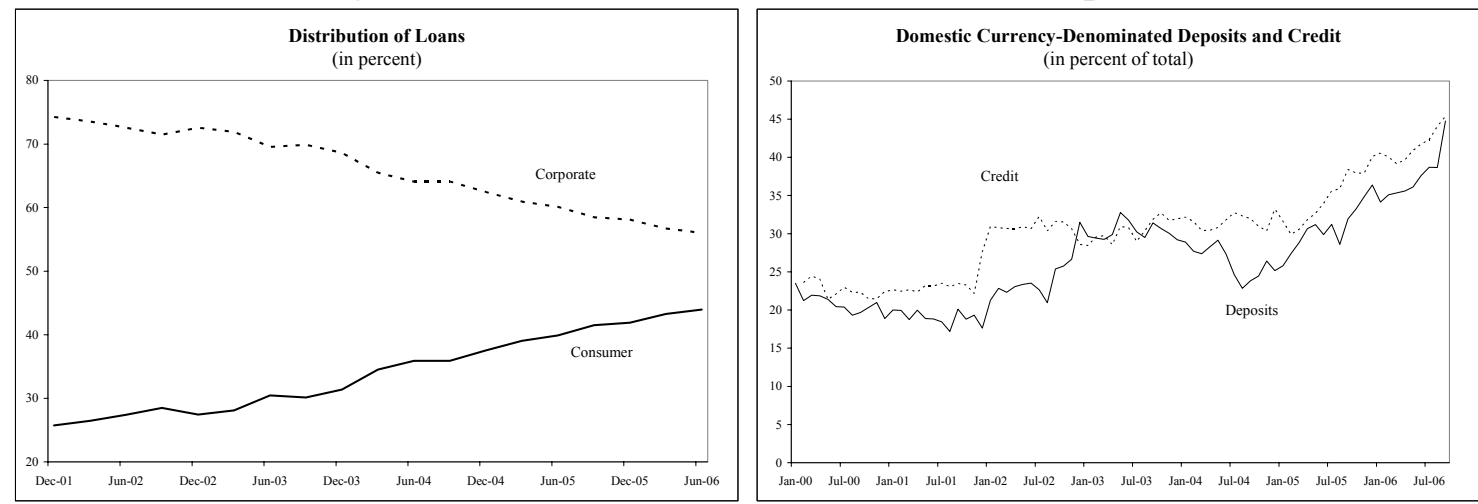

Sources: Armenian authorities; and MBTS database.

62. Financial Soundness Indicators (FSI) indicate that the Armenian banks are generally well capitalized, profitable, and liquid, with a satisfactory level of asset quality. Despite recent credit growth, average capital adequacy ratios have not declined significantly, indicating high retained earnings. Bank profitability is high, with average return ratios well above international standards. ${ }^{30}$ Bank profitability has benefited from continued high interest rate margins and broadly conservative strategies of commercial banks in the recent past. Most banks have liquid asset ratios well above the prudential limits. The share of nonperforming loans (NPL) was still comparatively low at 3 percent in mid-2006, but has risen somewhat since $2005 .{ }^{31}$ Most of the increase was in the category of "watch" loans.

\footnotetext{
${ }^{29}$ In the first half of 2006, mortgage loans grew by more than 50 percent in dram terms to AMD 17 billion.

${ }^{30}$ By mid-2006, only one bank had negative return ratios, while four banks reported losses at end-2005. Generally, the larger banks have more favorable profitability indicators than most of the smaller banks.

31 The CBA definition of NPLs includes watch loans but excludes loss loans. Until recently, there had been a significant backlog of loss loans, which were however fully provisioned.
} 
Figure III.10. Financial Soundness Indicators

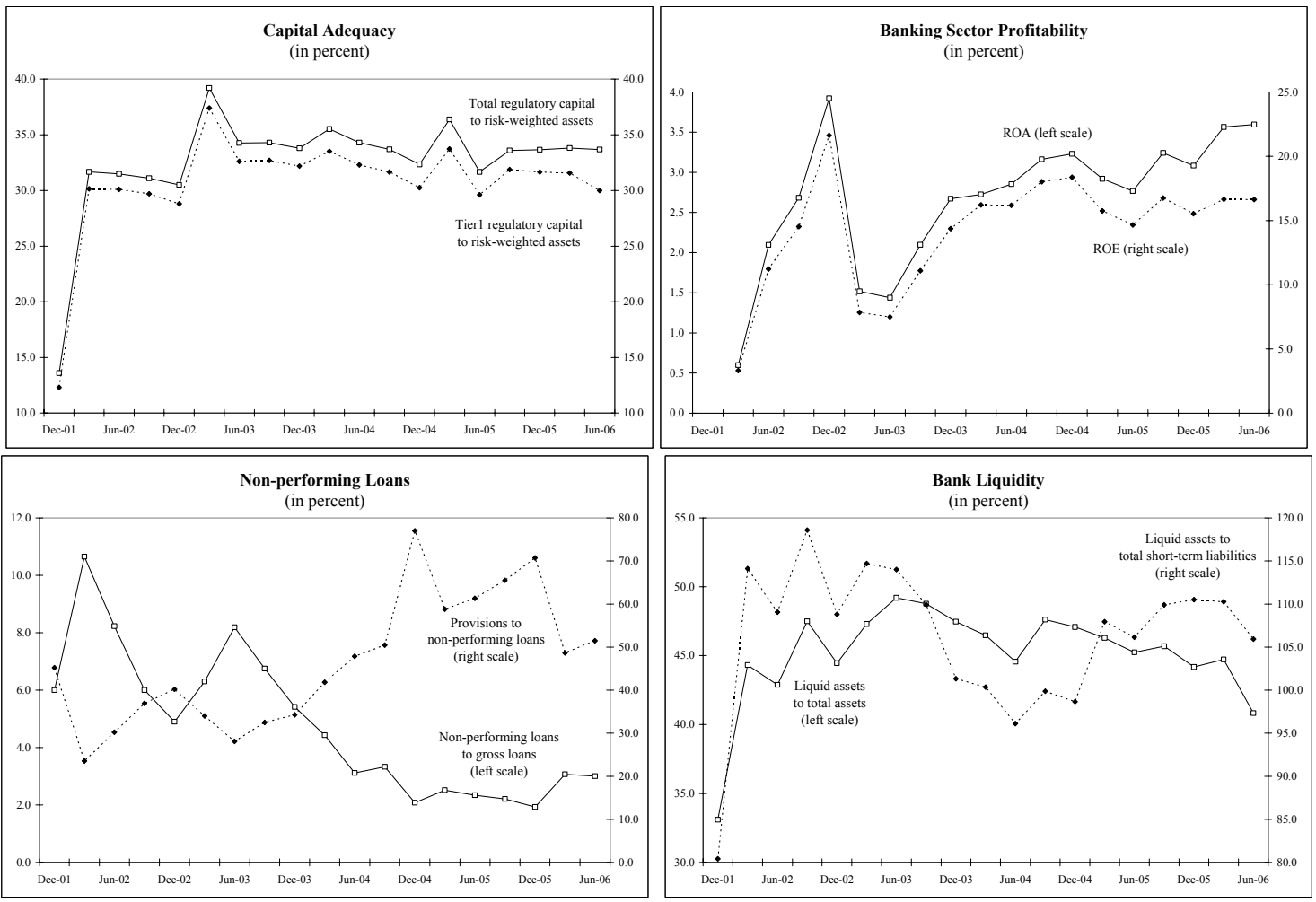

Source: Armenian authorities.

63. Indications are that financial deepening has been accelerating since 2004. Private sector credit growth has averaged at more than 30 percent. Bank deposit growth, while more volatile and somewhat lower, has exceeded 20 percent on average. While these developments are welcome, they also call for close monitoring of attendant risks and a strengthening of financial sector institutions with a view to maintaining macroeconomic and financial stability. The acceleration of growth in bank deposits and credit may contribute to a

Table III.1. Other Financial Institutions (2005)

\begin{tabular}{lr}
\hline Credit cooperatives (number) & 8 \\
loans/GDP (in percent) & 0.27 \\
Pawn shops (number) & 61 \\
loans extended/GDP (in percent) & 0.05 \\
funds attracted/GDP (in percent) & 0.03 \\
\hline
\end{tabular}
build-up in credit risk, which could stretch banks' capacity to assess and manage credit risks due to the increased volume of loans, especially if banks' investment in risk assessment does not keep pace with the rise in the volume of loans and shortcomings in corporate governance, accounting and reporting are not resolved. 
Figure III.11. Credit and Deposit Growth
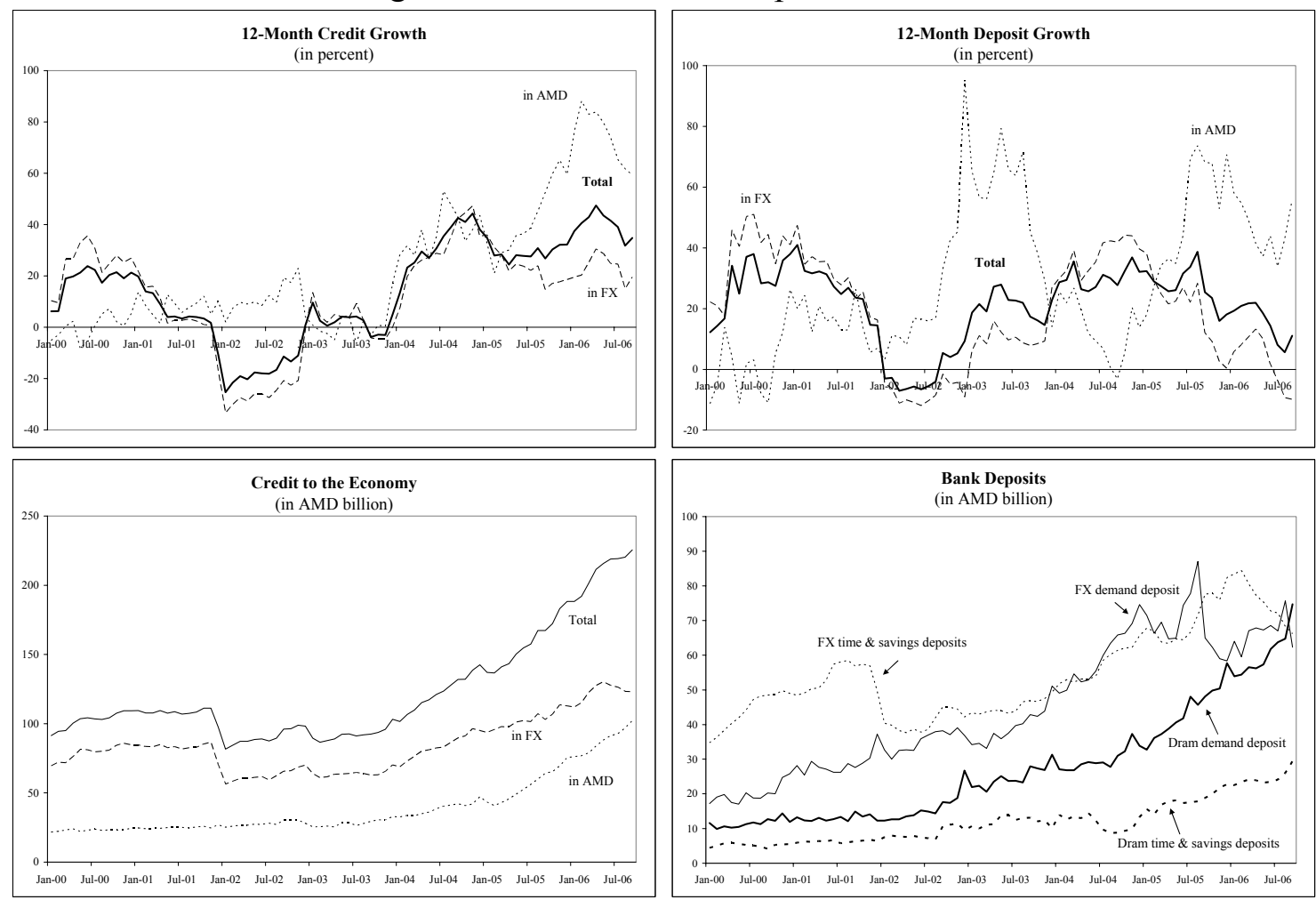

Source: MBTS database.

64. Nonbank financial intermediaries play a negligible role in Armenia. Insurance companies, microfinance institutions, credit cooperatives, and pension funds account for only around 3 percent of the total financial system assets. The insurance sector is small and underdeveloped, with annual premiums of only 0.1 percent of GDP. The vast majority of

Table III.2. Insurance Sector (2005)

Number of companies 24

Premium income/GDP (in percent) 0.1

Reinsurance outflows/Premium income (in percent) $\quad 98.0$ insurance contracts are reinsured abroad. Compulsory insurance (such as third-party liability auto insurance) has not yet been introduced.

65. Stock market capitalization is very low and trading thin in both equity and debt securities. Foreign exchange trading was introduced at the Armenian stock exchange (Armex) in November 2005. Despite the relative large number of shares admitted to trading at Armex, actual trading remains rudimentary. ${ }^{32}$ The low turnover of individual Table III.3. Capital Market (2005) shares makes it virtually impossible for brokers

\footnotetext{
${ }^{32}$ Many companies were listed only because of privatization during the mid-1990s. The number of listed companies was reduced significantly in 2006 by removing inactive companies and companies in liquidation.
} 
to rely on market prices as an indicator for the true value of a share. To date, the securities market has scarcely been used by companies to raise capital. The first corporate bond was listed in December 2005. In the future, further progress in privatization and the development of an equity culture may increase the supply of equity securities. Plans to develop pension and equity funds may in turn increase the demand for securities in the medium term.

\section{Obstacles to Financial Sector Development}

66. Armenia has a large shadow economy that does not rely on the formal banking sector for financial intermediation. Firms and individuals in the informal sector rely to a large extent on cash for transactions, partly to evade taxes. This significantly diminishes the potential deposit base of the banking system and the market for products offered by banks and other financial institutions. The substantial and rising inflows of remittances from abroad also provides a source of funds that reduces the need to obtain financing from the financial sector.

67. Depositor trust in the banking systems is still comparatively low, possibly resulting in high funding costs for local banks. The main reasons for the lack of trust appear to be the experience of bank failures in recent years and lack of bank transparency and accountability.

68. High banking spreads result in either a high cost of credit, which discourages borrowing, or a low remuneration of deposits, which discourages intermediation of savings, or both. The level of spreads in Armenia is mainly determined by (1) high perceived credit risk; (2) rents accruing from banks' market power on both the lending and deposit side; and (3) high funding and operating costs for smaller banks.

- Credit risk: High credit risk appears unrelated to macroeconomic conditions. Rather, it stems from the lack of a developed credit culture and weaknesses in the institutional infrastructure, which may inhibit the adoption of best practices in lending. Banks' ability to properly assess creditworthiness of borrowers and monitor credit risk is limited by insufficient risk management capabilities and the lack of reliable accounting and reporting standards. Weak creditor protection and judicial systems inhibit banks to rapidly repossess collateral in case of default. In addition, the banking sector still suffers from weak governance. Nontransparent ownership structures favor connected lending, which may result in either heightened risk or crowding out of borrowers seeking finance for potentially productive projects.

- $\quad$ Market power: Low banking competition owing to market segmentation tends to increase deposit-lending spreads because they enable banks to extract rents from borrowers and depositors. The only first-tier international bank operating in Armenia greatly benefits from its reputation and is market leader in the deposit business even though it doesn't pay interest on deposits and charges hefty fees for new deposits. 
- Operating and funding costs: Some banks may incur higher operating costs because they are not large enough to exploit scale economies. Smaller local banks may incur higher funding costs in the form of a "confidence premium" to attract deposits, as compensation for high perceived risk. ${ }^{33}$

\section{Financial Sector Reforms}

69. Armenia has achieved significant progress in bank supervision in recent years. The CBA conducts a rigorous supervisory process, with enforcement grounded in legislation, regulatory reporting, and prudential norms. Recent amendments to banking legislation have enhanced the regulatory and supervisory processes, as well as improved auditing and risk management. As a result, banking supervision legislation is now largely compliant with the Basel core principles. Ongoing regulatory reforms deal with further improving bank corporate governance, including the opaque bank ownership structures.

Table III.4. EBRD Transition Index and Financial Sector Reform

\begin{tabular}{|c|c|c|c|c|c|c|c|c|c|}
\hline & \multicolumn{3}{|c|}{$\begin{array}{c}\text { EBRD Transition Index } \\
\text { (overall average of } 14 \text { criteria) }\end{array}$} & \multicolumn{3}{|c|}{$\begin{array}{l}\text { Banking reform and } \\
\text { interest rate liberalisation }\end{array}$} & \multicolumn{3}{|c|}{$\begin{array}{c}\text { Securities markets and } \\
\text { non-bank financial institutions }\end{array}$} \\
\hline & 1994 & 2000 & 2005 & 1994 & 2000 & 2005 & 1994 & 2000 & 2005 \\
\hline Armenia & 1.54 & 2.59 & 2.86 & 1.00 & 2.33 & 2.67 & 1.00 & 2.00 & 2.00 \\
\hline Azerbaijan & 1.21 & 2.24 & 2.48 & 1.00 & 2.00 & 2.33 & 1.00 & 1.67 & 1.67 \\
\hline Belarus & 1.46 & 1.52 & 1.67 & 1.00 & 1.00 & 1.67 & 2.00 & 2.00 & 2.00 \\
\hline Georgia & 1.28 & 2.78 & 2.83 & 1.00 & 2.33 & 2.67 & 1.00 & 1.67 & 1.67 \\
\hline Kazakhstan & 1.51 & 2.59 & 2.76 & 1.00 & 2.33 & 3.00 & 1.67 & 2.33 & 2.33 \\
\hline Kyrgyz Republic & 2.20 & 2.33 & 2.48 & 2.00 & 2.00 & 2.33 & 1.00 & 2.00 & 2.00 \\
\hline Moldova & 1.80 & 2.62 & 2.67 & 2.00 & 2.33 & 2.67 & 2.00 & 2.00 & 2.00 \\
\hline Russia & 2.21 & 2.52 & 2.86 & 2.00 & 1.67 & 2.33 & 1.67 & 1.67 & 2.67 \\
\hline Tajikistan & 1.26 & 1.74 & 2.00 & 1.00 & 1.00 & 2.00 & 1.00 & 1.00 & 1.00 \\
\hline Turkmenistan & 1.10 & 1.24 & 1.19 & 1.00 & 1.00 & 1.00 & 1.00 & 1.00 & 1.00 \\
\hline Ukraine & 1.41 & 2.45 & 2.64 & 1.00 & 2.00 & 2.67 & 1.67 & 2.00 & 2.33 \\
\hline Uzbekistan & 1.67 & 1.81 & 2.05 & 1.00 & 1.67 & 1.67 & 2.00 & 2.00 & 2.00 \\
\hline Estonia & 2.82 & 3.62 & 3.69 & 3.00 & 3.67 & 4.00 & 1.67 & 3.00 & 3.33 \\
\hline Latvia & 2.62 & 3.12 & 3.38 & 3.00 & 3.00 & 3.67 & 2.00 & 2.33 & 3.00 \\
\hline Lithuania & 2.21 & 3.10 & 3.36 & 2.00 & 3.00 & 3.67 & 2.00 & 3.00 & 3.00 \\
\hline
\end{tabular}

Source: EBRD.

70. In contrast to progress in banking supervision, regulation and supervision of the nonbank financial sector is still in an early stage. In this regard, the recent establishment of a consolidated financial sector supervision framework is a stepping stone to improving supervision of both bank and nonbank financial institutions. New insurance legislation and securities market regulations in line with international standards as well as a major overhaul of the pension system are under preparation.

\footnotetext{
33 The leading bank in Armenia, a subsidiary of a large first-tier international bank, enjoys low average cost of funding, as depositors are willing to accept very low interest rates because of the perceived safety of deposits in this bank. In contrast, many domestic banks must offer much higher interest rates to attract deposits.
} 
Table III.5. World Bank Doing Business 2007 and Financial Sector Reform

\begin{tabular}{|c|c|c|c|c|c|c|c|c|c|}
\hline & \multicolumn{2}{|c|}{ Getting Credit } & \multicolumn{4}{|c|}{ Protecting Investors } & \multicolumn{3}{|c|}{ Enforcing Contracts } \\
\hline & $\begin{array}{l}\text { Legal Rights } \\
\text { Index }\end{array}$ & $\begin{array}{c}\text { Credit } \\
\text { Information } \\
\text { Index }\end{array}$ & $\begin{array}{l}\text { Disclosure } \\
\text { Index }\end{array}$ & $\begin{array}{c}\text { Director } \\
\text { Liability } \\
\text { Index }\end{array}$ & $\begin{array}{c}\text { Shareholder } \\
\text { Suits } \\
\text { Index }\end{array}$ & $\begin{array}{l}\text { Investor } \\
\text { Protection } \\
\text { Index }\end{array}$ & $\begin{array}{l}\text { Procedures } \\
\text { (number) }\end{array}$ & $\begin{array}{l}\text { Time } \\
\text { (days) }\end{array}$ & $\begin{array}{c}\text { Cost } \\
\text { (percent } \\
\text { of debt) }\end{array}$ \\
\hline Armenia & 5 & 3 & 5 & 2 & 8 & 5.0 & 24 & 185 & 14.0 \\
\hline Azerbaijan & 7 & 4 & 4 & 1 & 8 & 4.3 & 27 & 267 & 19.8 \\
\hline Belarus & 2 & 3 & 1 & 3 & 7 & 3.7 & 28 & 225 & 21.1 \\
\hline Georgia & 6 & 3 & 4 & 4 & 4 & 4.0 & 24 & 285 & 20.5 \\
\hline Kazakhstan & 5 & 4 & 7 & 1 & 9 & 5.7 & 37 & 183 & 11.5 \\
\hline Kyrgyz Republic & 5 & 3 & 8 & 1 & 9 & 6.0 & 44 & 140 & 12.0 \\
\hline Moldova & 6 & 0 & 7 & 1 & 6 & 4.7 & 37 & 310 & 16.2 \\
\hline Russia & 3 & 0 & 7 & 2 & 7 & 5.3 & 31 & 178 & 13.5 \\
\hline Tajikistan & 4 & 0 & 0 & 0 & 5 & 1.7 & 46 & 257 & 10.3 \\
\hline Ukraine & 8 & 0 & 1 & 3 & 7 & 3.7 & 28 & 183 & 16.0 \\
\hline Uzbekistan & 3 & 0 & 4 & 6 & 3 & 4.3 & 35 & 195 & 13.5 \\
\hline Estonia & 4 & 5 & 8 & 4 & 6 & 6.0 & 25 & 275 & 11.5 \\
\hline Latvia & 8 & 4 & 5 & 4 & 8 & 5.7 & 21 & 240 & 11.8 \\
\hline Lithuania & 4 & 6 & 6 & 4 & 6 & 5.3 & 24 & 166 & 8.6 \\
\hline OECD & 6.3 & 5.0 & 6.3 & 5.0 & 6.6 & 6.0 & 22.2 & 351 & 11.2 \\
\hline
\end{tabular}

Source: World Bank

71. Apart from various reforms of the regulatory and supervisory framework, the authorities have taken a number of important steps to foster the deepening of financial intermediation and to increase confidence in the Armenian banking system (CBA 2006):

- Deposit insurance: A new mandatory deposit insurance commenced coverage in 2005. The Deposit Insurance Law provides limited coverage of deposits of individuals (up to AMD 2 million [about US\$5,300]). The scheme is funded mainly by premiums paid by banks that are a fixed percentage of their deposits (currently 0.5 percent).

- Credit registry and credit bureau: A credit registry was introduced in Armenia in 2003, and a private credit bureau was established in 2004. These institutions reduce credit risk by creating an information system on the creditworthiness of borrowers.

- $\quad$ Strengthening creditor rights: Procedures on foreclosure of collateral were simplified and a procedure for the off-court foreclosure of collateral introduced during 2004-2005. In addition, a register for movable property collateral was created.

- Minimum capital requirements of banks were increased from US\$1 million to US\$5 million, with the purpose to foster banking sector consolidation and increase banks' resilience against credit risk.

- Measures to reduce the use of cash in transactions are being contemplated in an effort to contain activities in the informal economy and promote financial intermediation. 
- $\quad$ Regulations to foster the use of domestic currency were introduced, including the prohibition of pricing and payment in foreign exchange in the retail sector and a strengthening of the oversight of foreign exchange offices. Bank reserves are now required to match the currency denomination of bank deposits, which has shifted the supply of loanable funds from foreign to domestic currency.

- $\quad$ Armenia has obtained sovereign credit ratings from renowned international rating agencies. In 2006, Moody's and Fitch assigned sovereign ratings of Ba2 and BB-, respectively. The ratings will improve local banks' access to external sources of financing and are a prerequisite for the rating of Armenian corporations.

- $\quad$ AML/CFT framework: The AML/CFT framework is recognized as largely compliant with Basel Core Principles. Further improvements are being implemented with the help of Fund technical assistance.

72. A crucial step towards further improving financial intermediation will be the entry of additional top-tier international banks in the Armenian market. Increased foreign ownership would increase confidence in the banking sector by improving governance practices, competition, and technical and management expertise, in particular in the area of risk management. The recent purchase of $28 \%$ shares of ACBA by French Credit Agricole banking group and the announcement that Dutch ING group will provide consultative postal and postal-banking services for Armpost are welcome in this regard. Further consolidation of the banking sector may be required, but should proceed in a market-driven process.

73. Progress in tax administration reform will be crucial to promote the legalization of the informal economy. ${ }^{34}$ The large shadow economy remains one of the main obstacles to financial sector development. While the CBA is considering various measures to limit the use of cash and foreign exchange in transactions, improved tax administration would be the single most important measure to reduce the shadow economy.

74. Successful implementation of the planned pension reform and reforms in the insurance sector could contribute to the development of the financial system and capital markets in the longer term. An increase in the pension contribution rate would generate a large increase in savings that could be intermediated by the financial sector. At the same time, this creates risks, as the financial system is not yet well equipped to manage large additional savings. This points to the importance of the entry of reputable international market participants providing the needed asset management capacity.

\footnotetext{
${ }^{34}$ According to the World Bank's Doing Business 2007 report, Armenia's tax administration is very weak from an international perspective. In a ranking of 175 countries, Armenia is situated close to the bottom, $147^{\text {th }}$ position in the area of tax administration and $171^{\text {st }}$ on time and efforts for preparing of tax declarations.
} 
75. However, growth in nonbank financial markets appears to be less crucial than progress in the banking sector at the current stage of economic development. Domestic equity and private debt markets and nonbank financial institutions do not appear to have played a major role in the first phase of financial development of the most successful transition economies in Central and Eastern Europe. The expansion of private bond markets and nonbank financial institutions, such as insurance and pension funds, has commenced only much later (De Nicoló, Geadah, and Rozhkov, 2003).

\section{E. Conclusions}

76. Financial sector development in Armenia has lagged behind that in other transition countries in the past, and the financial sector has not contributed significantly to the strong economic growth performance of the Armenian economy. However, indications are that financial deepening is finally taking hold. Financial soundness indicators have been improving; confidence in the banking sector appears to be finally increasing as important financial sector reforms are taking effect; dedollarization is gaining momentum; and both private sector credit and deposit growth rates have accelerated. The envisaged entry of additional reputable international banks will enhance efficiency, competition, and confidence in the banking system.

77. Further strengthening and streamlining of the regulatory framework and prudential oversight is desirable to address the remaining obstacles to financial sector development and to limit emerging risks. The authorities' reform program increasingly focuses on the development of the nonbank financial sector. Tax administration reform will be crucial to contain the shadow economy and foster financial deepening.

78. While the immediate risks appear to be low, as banks are well capitalized and liquid, continued rapid credit growth without close monitoring and controlling the attendant risks would have the potential to compromise both macroeconomic and financial system stability. Credit quality may be heavily dependent on favorable macroeconomic conditions. Increased risks to financial stability may not become fully apparent until economic growth slows (Hilbers, Otker-Robe, Pazarbasioglu, and Johnsen, 2005). 


\section{References}

CBA, 2006, "Financial Sector Reforms," mimeo., Central Bank of Armenia.

Cottarelli, Carlo, Giovanni Dell’Ariccia, Ivanna Vladkova-Hollar, 2003, "Early Birds, Late Risers, and Sleeping Beauties: Bank Credit Growth to the Private Sector in Central and Eastern Europe and the Balkans," IMF Working Paper No. WP/03/213 (Washington: International Monetary Fund).

De Nicoló, Sami Geadah, and Dimitriy Rozhkov, 2003, "Financial Development in the CIS-7 Countries: Bridging the Great Divide," IMF Working Paper No. WP/03/205 (Washington: International Monetary Fund).

Hilbers, Paul, Inci Otker-Robe, Ceyla Pazarbasioglu, and Gudrun Johnsen, 2005, “Assessing and Managing Rapid Credit Growth and the Role of Supervisory and Prudential Policies," IMF Working Paper No. WP/05/151 (Washington: International Monetary Fund).

Levine, Ross, Norman Loayza, and Thorsten Beck, 2000, "Financial Intermediation and Growth: Causality and Causes," Journal of Monetary Economics, Vol. 46 (1), pp. 3177. 